\title{
Millennial-scale climatic variability between 340000 and 270000 years ago in SW Europe: evidence from a NW Iberian margin pollen sequence
}

\author{
S. Desprat ${ }^{1,2}$, M. F. Sánchez Goñi ${ }^{1}$, J. F. McManus ${ }^{2}$, J. Duprat ${ }^{1}$, and E. Cortijo ${ }^{3}$ \\ ${ }^{1}$ EPHE, UMR-CNRS 5805, EPOC, Université Bordeaux 1, Avenue des Facultés, 33405 Talence, France \\ ${ }^{2}$ Woods Hole Oceanographic Institution, Department of Geology and Geophysics, Woods Hole, MA 02543, USA \\ ${ }^{3}$ Laboratoire des Sciences du Climat et de l'Environnement, LSCE-Vallée, Bât. 12, avenue de la Terrasse, 91198 \\ Gif-Sur-Yvette cedex, France
}

Received: 13 February 2008 - Published in Clim. Past Discuss.: 28 March 2008

Revised: 2 December 2008 - Accepted: 19 December 2008 - Published: 6 March 2009

\begin{abstract}
We present a new high-resolution marine pollen record from NW Iberian margin sediments (core MD03-2697) covering the interval between 340000 and 270000 years ago, a time period centred on Marine Isotope Stage (MIS) 9 and characterized by particular baseline climate states. This study enables the documentation of vegetation changes in the north-western Iberian Peninsula and therefore the terrestrial climatic variability at orbital and in particular at millennial scales during MIS 9, directly on a marine stratigraphy. Suborbital vegetation changes in NW Iberia in response to cool/cold events are detected throughout the studied interval even during MIS 9e ice volume minimum. However, they appear more frequent and of higher amplitude during the 30000 years following the MIS 9e interglacial period and during the MIS 9a- 8 transition, which correspond to intervals of an intermediate to high ice volume and mainly periods of ice growth. Each suborbital cold event detected in NW Iberia has a counterpart in the Southern Iberian margin SST record. High to moderate amplitude cold episodes detected on land and in the ocean appear to be related to changes in deep water circulation and probably to iceberg discharges at least during MIS 9d, the mid-MIS 9c cold event and MIS 9b. This work provides therefore additional evidence of pervasive millennial-scale climatic variability in the North Atlantic borderlands throughout past climatic cycles of the Late Pleistocene, regardless of glacial state. However, ice volume might have an indirect influence on the amplitude of the millennial climatic changes in Southern Europe.
\end{abstract}

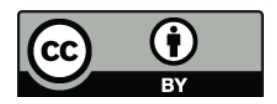

Correspondence to: S. Desprat (sdesprat@whoi.edu)

\section{Introduction}

An increasing number of studies on previous climatic cycles shows that millennial-scale variability is an inherent pattern of the Late Pleistocene climate affecting glacial periods (Bond et al., 1993; Bond and Lotti, 1995; Dansgaard et al., 1993; Grootes et al., 1993; Grimm et al., 2006; Allen et al., 1999; Sánchez Goñi et al., 2000) but also intervals of reduced ice volume such as the current or the last interglacial (Bond et al., 1997; Delmotte et al., 2004, EPICA community members, 2004; Martrat et al., 2004, 2007; McManus et al., 1999; Oppo and Lehman, 1995; Oppo et al., 1998, 2001, 2007). However, the origin of this variability remains unclear. Several hypotheses have been proposed including internal ocean oscillations, periodic calving of ice-sheets or solar forcing (Bond et al., 2001; Broecker et al., 1990; Mayewski et al., 1997; Sakai and Peltier, 1997; van Kreveld et al., 2000; van Geel et al., 1999).

So far, few studies have focused on the climatic variability of the interval between 340000 and 270000 years ago, encompassing the Marine Isotope Stage (MIS) 9 interglacial complex. Ruddiman (2007) recently called attention to this isotopic stage: based on the caloric summer half-year insolation, the early part of MIS 9 is the closest analog to the late Holocene throughout the last 450000 years. The Antarctica ice cores record during the MIS 9 peak interglacial the highest greenhouse gas concentrations of the past 650000 years, excluding the Holocene industrial period (Petit et al., 1999; Siegenthaler et al., 2005; Spahni et al., 2005). Pollen analysis, from the Southern Iberian margin core MD01-2443, revealed a suborbital vegetation change during the MIS 9e ice volume minimum bringing to an end the interglacial forest stage (Tzedakis et al., 2004b; Roucoux et al., 2006). These

Published by Copernicus Publications on behalf of the European Geosciences Union. 
authors pointed out the potential role of the suborbital climatic variability on the duration of the interglacials on land. MIS 9 is therefore a valuable complement to the better studied intervals such as MIS 5 or 11 to investigate the climate of interglacial periods.

Despite a different astronomical forcing but a similar range of sea level, the MIS 9 interval $~ 310-290 \mathrm{kyr}$ ago and MIS 3 are marked by a suborbital variability of similar pacing and amplitude in the Vostok deuterium record (Siddall et al., 2007). In the Southern Iberian margin region, frequent moderate to high amplitude decreases in sea surface temperatures (SST) strikingly punctuate the 30000 years following the MIS 9e interglacial period (Martrat et al., 2007). Over this period covering one and a half precession cycles, the summer insolation maximum at high latitudes was not particularly strong (Berger, 1978), $\mathrm{CO}_{2}$ concentrations decreased following a particular gradual trend (Petit et al., 1999) and although some sea level reconstructions give divergent results (Shackleton et al., 2000; Stirling et al., 2001), ice volume appears to have increased following a quite gradual general trend (McManus et al., 1999; Waelbroeck et al., 2002). The MIS 9 period gives, therefore, the opportunity to study the millennial-scale climatic variability under a particular combination of baseline climate states related to astronomical forcing, ice volume and greenhouse gas concentrations. Indeed, the millennial-scale climatic variability and the mechanisms associated will be better explained in studying periods characterized by different boundary conditions and in documenting the response of the different Earth's environments, such as the ocean or the vegetation, to the rapid climatic changes. However, the vegetation and terrestrial climate response to this high frequency climatic variability remains poorly known for the MIS 9 time interval.

We present here a high resolution marine pollen record covering the interval 340000-270000 years ago from the NW Iberian margin core MD03-2697. It will allow us to refine and characterize the sequence of suborbital climatic events affecting the Iberian region during MIS 9. Pollen analysis of marine sediments permits to perform a direct correlation of the terrestrial and marine climatic indicators and to record the vegetation changes against a marine isotopic timescale. Marine pollen sequences from the Iberian margin have already shown their particular ability to detect the millennialscale climatic variability and to delineate the linkage between atmospheric and oceanic changes over the current and previous periods (Desprat et al., 2005, 2006; Naughton et al., 2009; Roucoux et al., 2005, 2006; Sánchez Goñi et al., 1999, 2000, 2005, 2008; Tzedakis et al., 2004b).

According to the classical oxygen isotope stratigraphy, our 70000 year-long deep-sea record covers MIS 9 and partly MIS 8, including the isotopic events from 9.3 to 8.5 after the system of Prell et al. (1986). However, Tzedakis et al. (2004b), Roucoux et al. (2006) and Martrat et al. (2007) applied an alternative notation system to define the stratigraphy of the SW Iberian margin core over the interval 340-
270 kyr. This notation assigns five oxygen isotope substages within MIS 9 among which MIS "9a" and "9b" correspond to the intervals containing the isotopic events 8.5 and 8.6, respectively, and MIS "9e", "9d" and "9c" include the isotopic events 9.3, 9.2 and 9.1, respectively. The allocation of the light isotopic event 8.5 to the MIS 9 complex was originally suggested by Tzedakis et al. (1997) according to the major forest development characteristic of deglacial substages in Southern Europe which occurred at around that time. The direct land-sea correlation from SW Iberian margin confirmed that the isotopic event 8.5 actually occurs during a period of large forest extent in Southern Europe (Tzedakis et al.; 2004b). Moreover, although sea level reconstructions show similar lowstands during the 8.6 event and MIS 3, they display an 8.5 sea level maximum as high or higher than the 9.3 and 9.1 highstands (McManus et al., 1999; Shackleton et al., 2000; Siddall et al., 2003; Stirling et al., 2001; Waelbroeck et al., 2002) and generally of similar range to the 5.1 or 5.3 highstands (Shackleton et al., 2000; Siddall et al., 2003; Waelbroeck et al., 2002). For consistency between the Iberian margin and other paleoclimatic records suggesting that the isotopic event 8.5 likely belongs to a deglacial substage, we will follow throughout this paper the isotopic stage notation applied to the SW Iberian margin record.

\section{Environmental setting}

We examined sediments from the MIS 9 interval of core MD03-2697 which is located on the NW Iberian margin, at $\sim 100 \mathrm{~km}$ off the Galician coast $\left(42^{\circ} 09.6^{\prime} \mathrm{N}, 09^{\circ} 42.1^{\prime} \mathrm{W}\right.$, $2164 \mathrm{~m}$ ). This site is under the influence of the North Atlantic Deep Water (NADW) mass. The present-day climate of NW Iberia is temperate and humid with mean annual temperatures between 10 and $17^{\circ} \mathrm{C}$ and mean annual precipitation between 1000 and $2000 \mathrm{~mm} . \mathrm{yr}^{-1}$ (Atlas Nacional de España, 1992). This region is incised in the north by the Rias Baixas valleys (Galician coast basin) and the Miño-Sil river (Sil basin) (Atlas Nacional de España, 1993) and crossed in the south by the Douro river which are the main suppliers of terrestrial sediments to the shelf (Naughton et al., 2007). NW Iberia belongs to the Eurosiberian and sub-Mediterranean regions (Ozenda, 1982) where deciduous oak woodlands with heaths dominate (Alcara Ariza et al., 1987).

\section{Material and methods}

Core MD03-2697, retrieved in 2003 during the PICABIA campaign, consists of hemi-pelagic clays. The sedimentological description reveals apparently continuous sedimentation. We have carried out a multiproxy study of the sediments from the MIS 9 interval, including pollen analysis, stable oxygen isotope measurements from planktonic and benthic foraminifera and planktonic foraminifera counts and derived SST estimates. The MIS 9 interval in core MD03-2697 was 
initially located using planktonic $\delta^{18} \mathrm{O}$ profiles from the complete sedimentary sequence (Desprat, 2005).

\subsection{Isotopic analysis}

For the benthic foraminifera oxygen isotopic data, 42 levels were subsampled between 2860 and $3260 \mathrm{~cm}$ at 20,10,5 or $2 \mathrm{~cm}$ intervals between samples. Each specimen of benthic foraminifera (Cibicides wuellerstorfi) has been picked within the 250-315 $\mu \mathrm{m}$ grain-size fraction, and cleaned with distilled water. Each aliquot (4 to 8 specimens, representing a mean weight of $80 \mu \mathrm{g}$ ) has been prepared using a Micromass Multiprep autosampler, using an individual acid attack for each sample. The $\mathrm{CO}_{2}$ gas extracted has been analyzed against the NBS 19 standard, taken as an international reference standard. Isotopic analyses have been carried out at the Laboratoire des Sciences du Climat et l'Environnement (LSCE, Gif-sur-Yvette, France), using a delta plus Finnigan isotope mass spectrometer. All the isotopic results are presented versus PDB. The mean external reproducibility of powdered carbonate standards is $\pm 0.05 \%$ o for oxygen. Absence of the foraminifera species $C$. wuellerstorfi and $M$. barleeanus at the bottom of the studied interval precluded a benthic isotopic record of the MIS 10-9 glacial-interglacial transition.

The same preparation technique was applied to analyze stable oxygen isotopes of planktonic foraminifera from 70 levels subsampled at 20 to $2 \mathrm{~cm}$ intervals. The planktonic foraminifera Globigerina bulloides was used between 2860 and $3270 \mathrm{~cm}$ and Neogloboquadrina pachyderma left coiling over the intervals $2720-2860$ and $3260-3400 \mathrm{~cm}$.

3.2 Planktonic foraminifera quantitative climatic reconstruction

Summer and winter sea surface temperatures (SST) were estimated from planktonic foraminifera assemblages using the Modern Analogue Technique from the database of Pflaumann et al. (1996) improved by Cortijo (LSCE) and Duprat (EPOC UMR-CNRS 5805).

\subsection{Pollen analysis}

Pollen analysis was completed on 70 levels between 3300 and $2860 \mathrm{~cm}$ at 10 to $2 \mathrm{~cm}$ intervals. Pollen sample preparation followed the procedure described by de Vernal et al. (1996) and modified at EPOC UMR-CNRS 5805, Bordeaux I University (Desprat, 2005). After chemical and physical treatments using cold $\mathrm{HCl}$, cold $\mathrm{HF}$ and sieving through $10 \mu$ m nylon mesh screens, the residue was mounted unstained in glycerol. Pollen counts were achieved using a Zeiss Axioscope light microscope at 500 and 1250 (oil immersion) magnifications. A minimum of 100 pollen grains without Pinus and 20 taxa were identified in each sample. The pollen percentages for each taxon are based on a

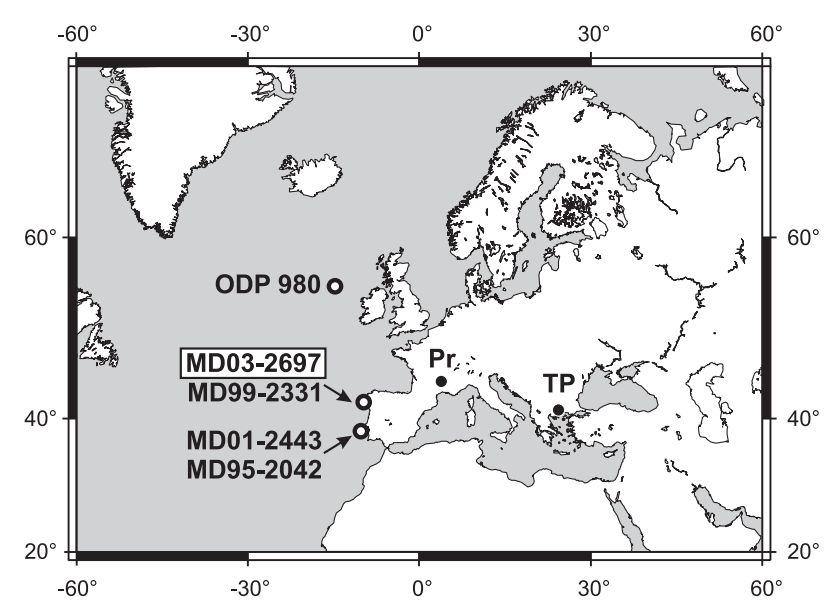

Fig. 1. Location of core MD03-2697 and other marine and terrestrial sequences discussed in the text (Pr: Praclaux; TP: Tenaghi Philippon).

main pollen sum that excludes Pinus because of its overrepresentation in marine sediments (Heusser and Balsam, 1977; Turon, 1984), aquatic plants, pteridophyte spores and indeterminable pollen grains. Pinus percentages were calculated from the main sum plus Pinus. Spores and aquatic pollen percentages were obtained from the total sum including pollen, spores, indeterminables and unknowns. We have defined the major forested phases as periods showing a classical tree succession which is known in Southern Europe and in particular in NW Iberia for beginning with the development of Betula, deciduous Quercus, and ending by the expansion of late successional trees such as Carpinus betulus and Fagus (Tzedakis et al., 2001; Desprat et al., 2007). Local names are given to these major forested periods.

\subsection{Chronology}

We established the chronology of core MD03-2697 by graphical correlation between its planktonic $\delta^{18} \mathrm{O}$ curve and that of core MD01-2443 located on the southern Iberian margin (Tzedakis et al., 2004b; Martrat et al., 2007). Based on the similarity between the benthic $\delta^{18} \mathrm{O}$ record of southern Iberian margin cores and Antarctic temperatures (Shackleton et al., 2000), the MD01-2443 benthic $\delta^{18} \mathrm{O}$ signal was aligned to the EPICA Dome $\mathrm{C}$ isotopic record (edc2 agescale) for developing the age model (Tzedakis et al., 2004b; Martrat et al., 2007). The low resolution of the MD03-2697 benthic $\delta^{18} \mathrm{O}$ signal and lack of measurements during Termination IV prevented development of an age-model for our core by lining up the benthic isotopic records. However, as both cores were retrieved from the Iberian margin, the major oscillations of their planktonic isotopic signals can be reasonably assumed synchronous. Despite the analysis-resolution difference, the MD01-2443 major planktonic $\delta^{18} \mathrm{O}$ changes are clearly identified in our sequence. We aligned 6 points of 


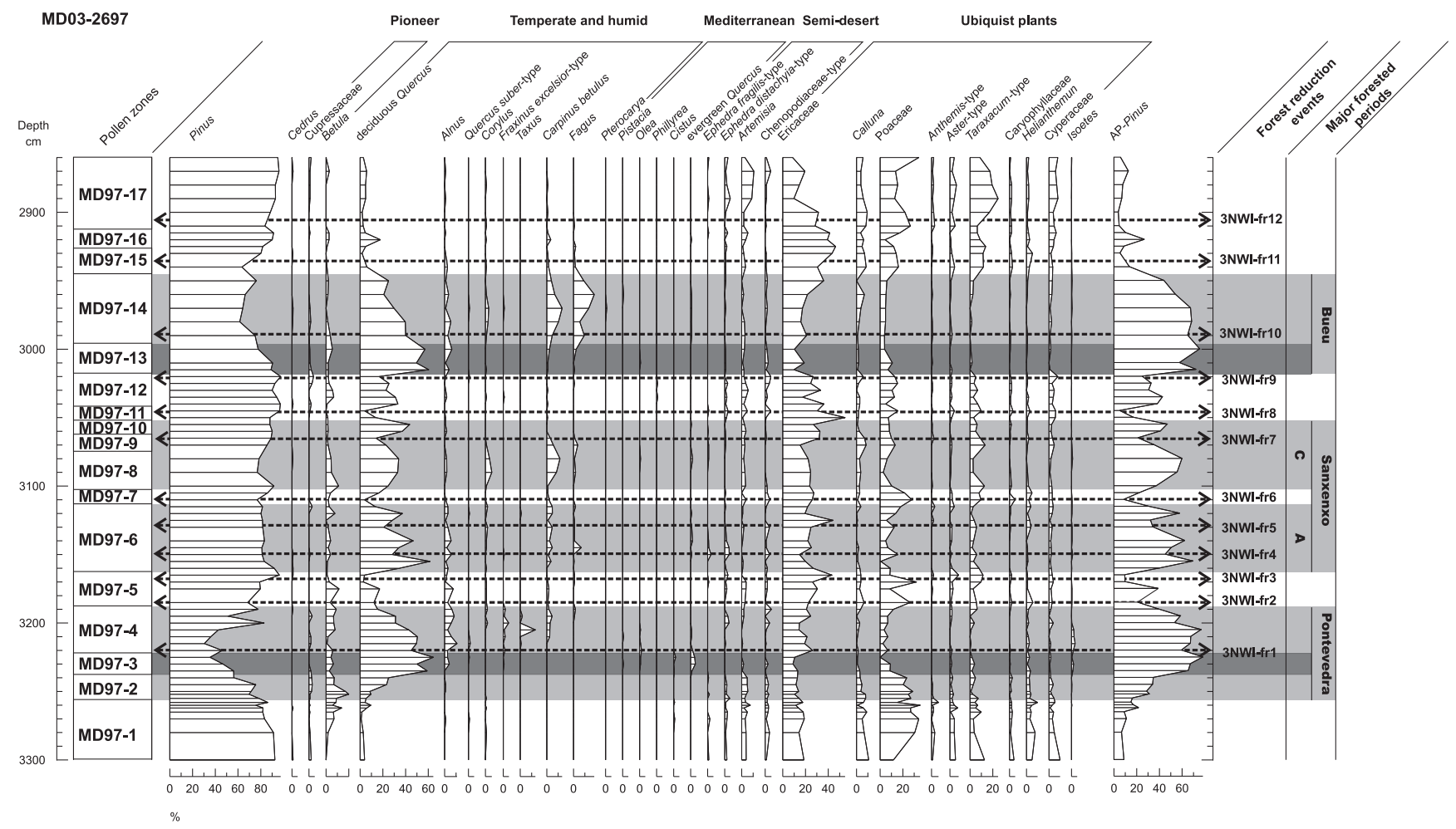

Fig. 2. Percentage pollen data versus depth for core MD03-2697. Pollen zones are indicated on the left of the diagram. Local names are given to the forest stages (grey areas). The maximum development of the temperate and humid forest during the Pontevedra and Bueu periods is highlighted in dark grey. Arrows underline abrupt vegetation changes which are named as following: 3- third climatic cycle, NWI: North-Western Iberia, fr- forest reduction, and number of the event.

heavier isotopic values and the first point of the light MIS 9e isotopic values over the record, obtaining a strong correlation $\left(r^{2}=0.86\right)$ between the MD03-2697 and MD01-2443 planktonic $\delta^{18} \mathrm{O}$ curves.

\section{The NW Iberian margin record - results and inter- pretation}

The main features of the MD03-2697 pollen record and inferred vegetation changes in NW Iberia during the MIS 9 interglacial complex are presented in Table 1, Fig. 2 and the direct land-sea correlation in Fig. 3. Pollen zones have been defined to characterize the major vegetation formation shifts. Three forest periods (Pontevedra, Sanxenxo and Bueu) (Table 1, Fig. 3) characterize each low ice volume intervals, i.e. substages $9 \mathrm{e}, 9 \mathrm{c}$ and $9 \mathrm{a}$, interspaced by two more or less open vegetation stages associated with high ice volume intervals, substages $9 \mathrm{~d}$ and $9 \mathrm{~b}$. In addition, forest reduction events have been identified (3NW-fr) during the forest stages and the open vegetation intervals on the basis of a decrease in the pollen percentages of the temperate and humid forest. However, these events do not always correspond to a distinct pollen zone because the change in the pollen assemblages can be not strong or long enough to unambiguously define a new pollen zone and then infer a vegetation formation shift.

Afforestation in NW Iberia generally began with Betula (birch), and deciduous Quercus (oak) followed by Alnus (alder), Corylus (hazel), Carpinus betulus (hornbeam), $\mathrm{Fa}$ gus (beech), Taxus (yew) or Pinus (pine). These trees are the dominant components of the temperate and humid forests established in Europe during the current interglacial. These forests are developing in the temperate regions where the moisture availability is not restricted. In NW Iberia, colder climatic conditions influence the vegetation cover by promoting forest opening. In our pollen record, increase of Ericaceae (heath) or dry-grassland taxa (mainly Poaceae, Taraxacum-type and semi-desert plants such as Artemisia, Ephedra distachya-type, Ephedra fragilis-type and Chenopodiaceae) at the expense of the tree taxa, characterizes the vegetation response to cold and cool events. More particularly, lower value of deciduous oak with heathland expansion suggests a cool and moist climate while the dominance of dry-grassland indicates cold and drier climate. 
Table 1. Description of the MIS 9 Northwestern Iberian margin pollen record. The last two columns show the millennial forest reduction events detected in core MD03-2697 (depth on which the event is centred is indicated) and the proposed correlation with the Iberian Margin Stadials displayed by the MD01-2443 $\mathrm{U}_{37}^{k^{\prime}}$-SST record (Martrat et al., 2007).

\begin{tabular}{|c|c|c|c|c|c|c|}
\hline $\begin{array}{l}\text { Forest } \\
\text { stages }\end{array}$ & $\begin{array}{l}\text { Pollen zones } \\
\text { (bottom depth in } \\
\mathrm{cm} \text {; age in kyr } \\
\text { BP) }\end{array}$ & $\begin{array}{l}\text { Number of } \\
\text { samples }\end{array}$ & Main features of the pollen assemblages & Vegetation formations & $\begin{array}{l}\text { Forest reduction } \\
\text { events included in } \\
\text { pollen zones }\end{array}$ & $\begin{array}{l}\text { Corresponding } \\
\text { cold events in the } \\
\text { MD01-2443 SST } \\
\text { record }\end{array}$ \\
\hline & $\begin{array}{c}\text { MD97-1 } \\
(3300 ; 339)\end{array}$ & 7 & $\begin{array}{l}\text { High values of Pinus, herbs taxa (mainly Poaceae) } \\
\text { and semi-desert taxa. Low Betula and } \\
\text { deciduous Quercus } \text { percentages. }\end{array}$ & $\begin{array}{l}\text { Dry grassland with birch and } \\
\text { deciduous oak woodlands and pine } \\
\text { populations }\end{array}$ & & \\
\hline \multirow[t]{5}{*}{ Pontevedra } & $\begin{array}{c}\text { MD97-2 } \\
(3256.5 ; 336.8)\end{array}$ & 5 & $\begin{array}{l}\text { Highest Betula values, continuous Cupressaceae } \\
\text { curve and deciduous Quercus percentages } \\
\text { increase. Steady Ericaceae and Artemisia values. } \\
\text { Fall of Pinus and Poaceae percentages. }\end{array}$ & $\begin{array}{l}\text { Establishment of a temperate and humid } \\
\text { forest with pioneer tree development }\end{array}$ & & \\
\hline & $\begin{array}{c}\text { MD97-3 } \\
(3237.5 ; 332.8)\end{array}$ & 3 & $\begin{array}{l}\text { Phase with maximum deciduous and evergreen } \\
\text { Quercus values, Alnus increase and Pistacia, Olea } \\
\text { and Cistus occurrences. Fall of herbs taxa and } \\
\text { Pinus percentages. }\end{array}$ & $\begin{array}{l}\text { Dominant deciduous oak forest with } \\
\text { some Mediterranean plants }\end{array}$ & & \\
\hline & $\begin{array}{c}\text { MD97-4 } \\
(3222.5 ; 329.7)\end{array}$ & 7 & $\begin{array}{l}\text { High deciduous Quercus values: at } 3220 \mathrm{~cm} \text {, oak } \\
\text { values reduced associated with a peak of } \\
\text { Ericaceae, at } 3210 \mathrm{~cm} \text { maximum percentages, from } \\
3205 \mathrm{~cm} \text { declining values. Increase of Alnus } \\
\text { and Taxus peak. Occurrence of Betula, Carpinus } \\
\text { betulus, Fraxinus excelsior-type, Fagus and } \\
\text { Corylus semi-desert taxa. Increase of Pinus and } \\
\text { Ericaceae percentages. }\end{array}$ & $\begin{array}{l}\text { Deciduous oak forest with groves of } \\
\text { alder, yew, hornbeam, birch, hazel, } \\
\text { beech and ash, and heathland }\end{array}$ & $\begin{array}{l}3 \mathrm{NWI}-\mathrm{fr} 1 \\
(3220 \mathrm{~cm})\end{array}$ & N/A \\
\hline & $\begin{array}{c}\text { MD97-5 } \\
(3187.5,322.4)\end{array}$ & 4 & $\begin{array}{l}\text { Low values of deciduous Quercus and Betula } \\
\text { (first minimum at } \sim 3185 \mathrm{~cm} \text { and second one at } \sim 3180 \mathrm{~cm} \text { ), }\end{array}$ & $\begin{array}{l}\text { Heathland and grassland with temperate } \\
\text { taxa woodlands and pine populations }\end{array}$ & $\begin{array}{l}3 \text { NWI-fr2 } \\
(3185 \mathrm{~cm})\end{array}$ & 3IMS-15 \\
\hline & & & $\begin{array}{l}\text { Corylus, Carpinus betulus and Fagus occurrences. } \\
\text { High Pinus, Poaceae, Taraxacum-type } \\
\text { and Ericaceae percentages }\end{array}$ & & $\begin{array}{l}3 \mathrm{NWI}-\mathrm{fr} 3 \\
(3180 \mathrm{~cm})\end{array}$ & 3IMS-14 \\
\hline \multirow[t]{8}{*}{ Sanxenxo } & $\begin{array}{c}\text { MD97-6 } \\
(3162.5 ; 317.3)\end{array}$ & 9 & $\begin{array}{l}\text { Phase with deciduous Quercus, Alnus, Carpinus } \\
\text { betulus, Ericaceae and Poaceae. Mediterranean }\end{array}$ & $\begin{array}{l}\text { Open oak forest with hornbeam, beech } \\
\text { and evergreen oak groves and with }\end{array}$ & $\begin{array}{l}3 \text { NWI-fr4 } \\
(3150 \mathrm{~cm})\end{array}$ & N/A \\
\hline & & & $\begin{array}{l}\text { taxa occurrence. Sharp fluctuations of deciduous } \\
\text { Quercus (minima at } 3150 \text { and } 3130 \mathrm{~cm} \text { ), } \\
\text { in favour of Ericaceae and Poaceae }\end{array}$ & heathland and grassland & $\begin{array}{l}3 \text { NWI-fr5 } \\
(3130 \mathrm{~cm})\end{array}$ & 3IMS-13 \\
\hline & $\begin{array}{c}\text { MD97-7 } \\
(3112.5 ; 307.8)\end{array}$ & 2 & $\begin{array}{l}\text { Phase dominated by NAP taxa, in particular Poaceae, } \\
\text { Taraxacum-type and Ericaceae. High Pinus } \\
\text { percentages. Low values of deciduous Quercus and } \\
\text { Betula (minimum at } 3110 \mathrm{~cm} \text { ). }\end{array}$ & $\begin{array}{l}\text { Grassland and heathland with } \\
\text { deciduous oak and birch groves }\end{array}$ & $\begin{array}{l}3 \text { NWI-fr6 } \\
(3110 \mathrm{~cm})\end{array}$ & 3IMS-12 \\
\hline & $\begin{array}{c}\text { MD97-8 } \\
(3102.5 ; 306)\end{array}$ & 3 & $\begin{array}{l}\text { Betula peak at the beginning, high deciduous Quercus, } \\
\text { Carpinus betulus and Corylus percentages. } \\
\text { Fagus occurrence. Small decrease of Pinus values. } \\
\text { Decreasing NAP taxa values but steady } \\
\text { Ericaceae percentages }\end{array}$ & $\begin{array}{l}\text { Mixed deciduous oak-hornbeam-hazel } \\
\text { forest with beech groves }\end{array}$ & & \\
\hline & $\begin{array}{c}\text { MD97-9 } \\
(3075 ; 301.2)\end{array}$ & 2 & $\begin{array}{l}\text { Decrease of deciduous Quercus, Carpinus betulus } \\
\text { and Corylus (minimum at } 3165 \mathrm{~cm} \text { ). Fagus occurrence. } \\
3165 \mathrm{~cm} \text { ). High Pinus values. Poaceae, Taraxacum } \\
\text {-type and Calluna rise }\end{array}$ & Open deciduous forest with grassland & 3NWI-fr7 & 3IMS-11 \\
\hline & $\begin{array}{c}\text { MD97-10 } \\
(3062.5 ; 299.1)\end{array}$ & 2 & Phase with deciduous Quercus peak, Ericaceae and Pinus & Open oak forest with heathland & & \\
\hline & $\begin{array}{c}\text { MD } 97-11 \\
(3052.5 ; 297.3)\end{array}$ & 2 & $\begin{array}{l}\text { Drop of AP taxa excluding Pinus (minimum at } 3045 \mathrm{~cm} \text { ). } \\
\text { High Ericaceae, Poaceae, Taraxacum-type, } \\
\text { Cyperaceae and Pinus percentages. Semi-desert taxa } \\
\text { values increase }\end{array}$ & Heathland and grassland & $\begin{array}{l}3 \text { NWI-fr8 } \\
(3045 \mathrm{~cm})\end{array}$ & 3IMS-10 \\
\hline & $\begin{array}{c}\text { MD97-12 } \\
(3042.5 ; 295.6)\end{array}$ & 5 & $\begin{array}{l}\text { Phase with intermediate values of deciduous Quercus } \\
\text { and Betula ( minimum at } 3020 \mathrm{~cm} \text { ), mesic } \\
\text { taxa occurrence. High Pinus, Ericaceae, Poaceae and } \\
\text { semi-desert taxa percentages. }\end{array}$ & $\begin{array}{l}\text { Open temperate and humid forest } \\
\text { with heathland }\end{array}$ & $\begin{array}{l}\text { 3NWI-fr9 } \\
(3020 \mathrm{~cm})\end{array}$ & 3IMS-9 \\
\hline \multirow[t]{5}{*}{ Bueu } & $\begin{array}{c}\text { MD97-13 } \\
(3017.5 ; 291.2)\end{array}$ & 3 & $\begin{array}{l}\text { Phase with high deciduous Quercus percentages and } \\
\text { continuous Alnus, Carpinus betulus and } \\
\text { Fagus curves. Pinus decrease. Low Poaceae and } \\
\text { Ericaceae values }\end{array}$ & $\begin{array}{l}\text { Deciduous temperate and humid forest } \\
\text { with oak dominance }\end{array}$ & & \\
\hline & $\begin{array}{c}\text { MD97-14 } \\
(2995 ; 287.3)\end{array}$ & 5 & $\begin{array}{l}\text { Decreasing values of deciduous Quercus. Rise of } \\
\text { Corylus, Carpinus betulus and Fagus } \\
\text { percentages. Lower Pinus percentages. Low semi- } \\
\text { desert taxa and Poaceae values. First deciduous Quercus } \\
\text { decrease associated with Ericaceae small peak at } 2990 \mathrm{~cm} \text {. }\end{array}$ & $\begin{array}{l}\text { Mixed hornbeam-beech-deciduous oak } \\
\text { forest with hazel groves }\end{array}$ & $\begin{array}{l}3 \text { NWI-fr10 } \\
(2990 \mathrm{~cm})\end{array}$ & N/A \\
\hline & $\begin{array}{c}\text { MD97-15 } \\
(2945 ; 278.6)\end{array}$ & 2 & $\begin{array}{l}\text { Carpinus betulus, Fagus and deciduous Quercus fall } \\
\text { (minimum at } 2930 \mathrm{~cm} \text { ). NAP taxa rise } \\
\text { (mainly Ericaceae, Poaceae and Taraxacum-type) }\end{array}$ & $\begin{array}{l}\text { Heathland and grassland with relics of } \\
\text { temperate and humid forest }\end{array}$ & $\begin{array}{l}\text { 3NWI-fr11 } \\
(2930 \mathrm{~cm})\end{array}$ & 3IMS-8 \\
\hline & $\begin{array}{c}\text { MD97-16 } \\
(2927.5 ; 275.9)\end{array}$ & 3 & $\begin{array}{l}\text { Phase with high Ericaceae and Pinus values. Deciduous } \\
\text { Quercus and Betula peaks. Decrease of } \\
\text { Taraxacum-type and Poaceae }\end{array}$ & Heathland with oak and birch groves & & \\
\hline & $\begin{array}{c}\text { MD97-17 } \\
(2912.5 ; 274.9)\end{array}$ & 6 & $\begin{array}{l}\text { Rise of the herbs taxa (mainly Poaceae, Taraxacum-type } \\
\text { and Cyperaceae) and semi-desert plants. } \\
\text { High Pinus values. Ericaceae decrease. Low deciduous } \\
\text { Quercus values }\end{array}$ & $\begin{array}{l}\text { Open vegetation dominated by grasses } \\
\text { (Poaceae and Taraxacum) and heath } \\
\text { with relics of temperate and humid } \\
\text { forest }\end{array}$ & $\begin{array}{l}\text { 3NWI-fr12 } \\
(2910 \mathrm{~cm})\end{array}$ & 3IMS-7 \\
\hline
\end{tabular}




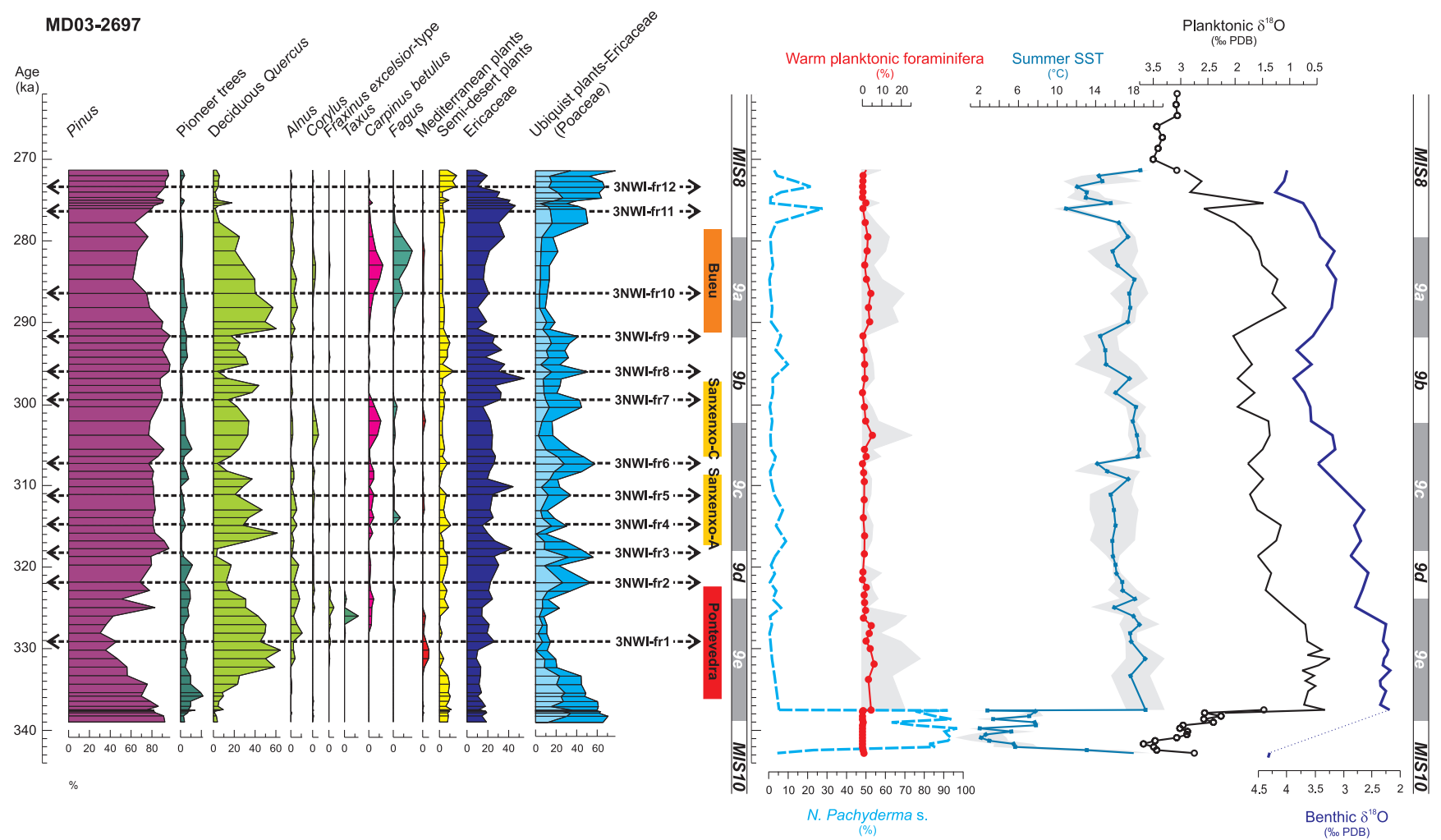

Fig. 3. MD03-2697 direct land-sea correlation. Pollen percentages of the main taxa and ecological groups (left panel): pioneer trees (Betula, Cupressaceae and Hippophae), Mediterranean plants (evergreen Quercus, Pistacia, Olea, Phillyrea and Cistus), semi-desert plants (Ephedra distachya-type, Ephedra fragilis-type, Artemisia and Chenopodiaceae) and ubiquist plants without Ericaceae (all herbaceous taxa excluding semi-desert taxa). Poaceae which is the main component of the ubiquist plant group is shown in light blue. Arrows underline the abrupt NW Iberian forest reductions. Marine data (right panel): planktonic foraminifera percentages of polar ( $N$. pachyderma s.) and warm (tropical and subtropical) species as defined in Bé (1977), summer sea surface temperatures SST $\left({ }^{\circ} \mathrm{C}\right)$ derived from planktonic foraminifera assemblages, planktonic and benthic $\delta^{18} \mathrm{O}$ data. Shaded areas show the 10 times exaggeration of warm planktonic foraminifera percentages and the SST estimation error. In between the pollen diagram and marine data, the forest stages and assigned names (colour bars) as well as the marine isotopic substages (white and grey bands) are indicated.

\subsection{The forest stages in NW Iberia}

The first forest stage (Pontevedra, 12 kyr duration), which is associated with the low ice volume substage 9e, displays a maximum expansion of deciduous oak forest and Mediterranean plants (evergreen Quercus, Olea and Pistacia) between 333 and $331 \mathrm{ka}$ (MD97-3, Fig. 2). This reveals the warmest interval of this period that we define as the climatic optimum in NW Iberia. The climatic optimum coincides with the lightest planktonic $\delta^{18} \mathrm{O}$ values and the maximum development of the warmest planktonic species of MIS 9, with summer SST estimates at around $19^{\circ} \mathrm{C}$, similarly to the Holocene Iberian SST reconstruction (Naughton, 2007). However, the ocean surface warmed quickly before the beginning of the Pontevedra period and afforestation shown by the expansion of birch and deciduous oak occurred progressively over $\sim 3000$ years. Although the lack of data precludes the identification of the real beginning of the MIS 9e benthic isotopic plateau, the record shows that the lightest benthic $\delta^{18} \mathrm{O}$ values are reached before the maximum development of the deciduous forest and Mediterranean plants.

An abrupt decrease of deciduous oak populations at $\sim 330 \mathrm{ka}$, principally in favour of heath, corresponds to the first forest reduction (3NWI-fr1 within pollen zone MD974) and reflects a cool and moist climatic oscillation of weak amplitude. It marks the end of the climatic optimum in NW Iberia. Subsequently, deciduous oak populations weakly reexpanded before beginning to reduce as yew, hornbeam and finally beech developed. The late expansion of these trees, considered as late successional, probably reveals a temperature decrease on the continent rather than the result of migration time and competition (see Prentice et al., 1991 for discussion) because the planktonic foraminifera assemblages indicate a concomitant $3^{\circ} \mathrm{C}$ summer SST drop and $\delta^{18} \mathrm{O}$ values increase. This change is also contemporaneous with the end of the benthic isotopic plateau suggesting an initial 
accumulation of glacial ice at high latitudes. However, the Pontevedra interval ends $\sim 2 \mathrm{kyr}$ later than substage 9e. This land and ocean cooling interval characterizes the second part of Pontevedra. The climatic optimum of this interval and the end-phase cooling observed on land are synchronously recorded in the ocean.

Deciduous oak forest briefly reached an expansion similar to that of Pontevedra at the beginning of the Sanxenxo period (-A) but in general the forest cover remained less extensive. Summer SST estimations indicate warm conditions $\left(\sim 18^{\circ} \mathrm{C}\right)$ during the third part of the Sanxenxo interval (-C) but do not show a warming during the first part of the Sanxenxo (-A) probably because of the relatively high $N$. pachyderma s. percentages $(\sim 8 \%)$. Such polar foraminifera percentages seem quite anomalous as the planktonic $\delta^{18} \mathrm{O}$ signal would indicate a warming at the beginning of Sanxenxo. Moreover, the error on the summer SST estimations is large during the whole Sanxenxo-A interval. The Sanxenxo period which mainly occurs during the interglacial substage MIS 9c, is also characterized by the development of late succesional trees such as hornbeam and, in a less extent, beech. However, the associated benthic $\delta^{18} \mathrm{O}$ values are not clearly lighter than during MIS $9 \mathrm{~d}$ and began to decrease quickly at $312 \mathrm{ka}$. This forested period is prolonged into MIS $9 \mathrm{~b}$ by $\sim 5 \mathrm{kyr}$.

Interestingly, in addition to a relatively smaller extent of the temperate and humid forest, the Sanxenxo period can be distinguished by abrupt fluctuations of the deciduous oak forest in favour of heathland or grassland (events $3 \mathrm{NWI}-\mathrm{fr} 4$, fr5, fr6, fr7). This suggests millennial-scale cooling events in NW Iberia at around 314, 311, 307 and $300 \mathrm{ka}$. The major event 3NWI-fr6 ( $\sim 307 \mathrm{ka})$ is a two-millennia cold episode during which the forest collapsed, explaining our division of this period into Sanxenxo-A and -C. Summer SST estimations clearly record this cold suborbital event by a decrease of $\sim 3^{\circ} \mathrm{C}$ but do not show a SST cooling during the other events detected on land. However, this could be an artefact due to the lower time-resolution of the marine proxy records and to the anomalously high $N$. pachyderma s. percentages.

In contrast to Sanxenxo, the last forested period of MIS 9 (Bueu) is associated with a longer benthic $\delta^{18} \mathrm{O}$ decrease which corresponds to the $9 \mathrm{a}$ isotopic substage, although its bottom and upper boundaries lag by $\sim 1 \mathrm{kyr}$ the isotopic substage limit. The first phase of this forest stage (MD97-13) is marked by a temperate and humid forest development as large as during Pontevedra, but Meditterranean plants did not expand. This first phase corresponds to the warmest conditions of Bueu forest stage and ends abruptly at $\sim 287 \mathrm{ka}$ (3NWI-fr10) by a decrease of deciduous oak in favour of Ericaceae. During the second phase of this forest stage (MD97-14), hornbeam and beech which grow preferentially in moister and cooler conditions than deciduous oak, play an important role. The interval $\sim 284-280$ ka corresponds to the largest expansion of hornbeam and beech during MIS 9 and to a $2^{\circ} \mathrm{C} \mathrm{SST} \mathrm{decrease.}$
The observed long-term completeness of the sequential tree succession during the Pontevedra, Sanxenxo and Bueu intervals and large temperate and humid forest expansion define them as interglacials in NW Iberia. In contrast, during the following MIS 8 period the interval corresponding to pollen zone MD97-16 shows the increase of deciduous Quercus and Betula indicating a minor warm and wet event that we define as an interstadial.

\subsection{The major open vegetation intervals in NW Iberia}

Besides the minor forest reductions punctuating the three major forested periods (interglacials), our record detects several major open vegetation intervals. The interval between the Pontevedra and the Sanxenxo (MD97-5) is characterized by the establishment of an open vegetation cover dominated by heathland and grassland. Two forest extent minima (3NWIfr2 and fr3) are detected during this interval at $\sim 322$ and $318 \mathrm{ka}$. The summer SST cooled gradually by $\sim 2^{\circ} \mathrm{C}$ during this interval though the $\delta^{18} \mathrm{O}$ indicates a two-step cooling. This open vegetation period is associated with the MIS 9d substage although their time boundaries are different.

Between Sanxenxo and Bueu (MD97-11 and -12), the summer SST cooled by $3^{\circ} \mathrm{C}$, planktonic $\delta^{18} \mathrm{O}$ values were relatively heavy and the NW Iberian landscape was dominated by herbaceous plants, in particular heathland and drygrassland. Oak populations decreased strongly at $\sim 296 \mathrm{ka}$ (3NWI-fr8), reflecting a strong and abrupt cold event in NW Iberia. A weaker deciduous tree reduction occurs also at $292 \mathrm{ka}$ (3NWI-fr9), just before the rapid oak forest expansion associated with the beginning of the Bueu period.

Finally, while the benthic $\delta^{18} \mathrm{O}$ increases towards the MIS 8 glacial values, herbaceous communities became largely dominant, suggesting the establishment of the glacial cold conditions (MD97-15 to -17). However, three intervals can be distinguished during this transition. The end of the Bueu forested period is marked by an abrupt decrease of the forest (3NWI-fr11), which is synchronous with a peak in N. pachyderma s. and a $5^{\circ} \mathrm{C}$ summer SST cooling. At around $276 \mathrm{ka}$, some woodlands of birch, oak, hornbeam and hazel expanded while grassland decreased, summer SST increased and planktonic $\delta^{18} \mathrm{O}$ became lighter. And finally, the end of the record is marked by a vegetation cover dominated by grassland (3NWI-fr12) accompanied by a new peak in $N$. pachyderma s. and a $3^{\circ} \mathrm{C}$ cooling in summer SST. These changes reflect a cold-warm-cold oscillation succession which occurred contemporaneously on land and in the surface ocean during the MIS 9-8 transition. 


\section{Discussion}

5.1 Climatic variability at orbital scale: the major warm periods

The MIS 9 marine pollen record off Galicia shows the response of the NW Iberian vegetation at orbital scale by detecting three major periods of temperate and humid forest development (Pontevedra, Sanxenxo, Bueu) related to the marine isotope substages $9 \mathrm{e}, 9 \mathrm{c}$ and $9 \mathrm{a}$. The relative degree of climatic amelioration between these periods can be inferred from the forest character and extent, in particular according to the expansion of deciduous oak forest and Mediterranean plants. As the development of deciduous oak and Mediterranean plants reach a maximum extent during Pontevedra, this forest stage does represent the warmest period of MIS 9 in NW Iberia. In particular, the warmest conditions are reached during a 2 kyr-long interval ( $~ 333-331 \mathrm{ka})$ corresponding to the climatic optimum. Because of a moderate deciduous forest expansion, the Sanxenxo interval appears as a period of intermediate climatic amelioration between the forest stages Pontevedra and Bueu occurring during MIS 9e and MIS 9a, respectively. As mentioned earlier, although the Bueu period presents a striking prominent expansion of deciduous trees as large as the Pontevedra period, the virtual absence of most of the Mediterranean taxa during the maximum expansion of deciduous oak and the large development of Fagus and Carpinus indicate that the Bueu climatic amelioration is weaker than that of the Pontevedra. Such relative difference of forest extent and climatic amelioration between the three forested periods are commonly recognized in the long Southern European pollen sequences Tenaghi Philippon (Tzedakis et al., 2003; Wijmstra and Smit, 1976) and Praclaux (Reille and de Beaulieu, 1995; Reille et al., 2000) and the SW Iberian margin pollen record MD01-2443 (Tzedakis et al., 2004b; Roucoux et al., 2006).

In a review of the long Southern European pollen records, Tzedakis (2005) pointed out a broad correspondence between ice volume and Southern European forest changes over the previous glacial cycles. However, ice volume and vegetation changes are not in parallel: each forest period corresponds to a light oxygen isotope substage but their boundaries are generally not isochronous (Tzedakis et al., 2004b; Tzedakis, 2005; Shackleton et al., 2003). In particular, the forest expansions in SW Iberia lag by 1 to $2.5 \mathrm{kyr}$ the beginning of the isotopic substages $9 \mathrm{e}, 9 \mathrm{c}$ and $9 \mathrm{a}$, and the forest declines, in particular at the end of Lisboa and Mafra terrestrial stages (Fig. 4), ended well before the marine stage boundaries (Tzedakis et al., 2004b). Although the low time resolution of the benthic isotopic signal in our record precludes establishing an accurate timing, the NW Iberian direct land-sea correlation also shows asynchronous marine and forest stage boundaries. The beginning of forest stages in NW Iberia also lags the bottom limit of the corresponding isotopic substage but in contrast to the SW Iberian record, the end of the forest stages always lags the upper limit of the marine substages. In Southern Europe, the amplitude of forest development during temperate intervals would exhibit an apparent closer relationship with summer insolation changes at $65^{\circ} \mathrm{N}$ than with ice volume extent, due to a direct vegetation response to climate regimes (Tzedakis et al., 2003; Tzedakis, 2005). Indeed, both forest expansion in NW Iberia and $65^{\circ} \mathrm{N}$ summer insolation are maximum during substage $9 \mathrm{e}$, and weaker during MIS 9c than during MIS 9a (Fig. 5). However, the relationship between the degree of forest expansion and ice volume extent within the MIS 9 interval still remains difficult to state due to the uncertainties of the available sea level reconstructions. All the sea level reconstructions show the highest period during the MIS 9e interval but they display an MIS 9a highstand from equivalent to largely higher than that of MIS 9c (Lea et al., 2002; McManus et al., 1999; Siddall et al., 2003; Shackleton et al., 2000; Stirling et al., 2001; Waelbroeck et al., 2002).

Like the European pollen sequences, marine records from the North Atlantic agree to allocate the MIS 9 climatic optimum during the isotopic substage 9e (Figs. 4 and 5). The highest SST from cores MD03-2697, MD01-2443 (Martrat et al., 2007) and ODP 980 (McManus et al., 1999) appear concurrent to the warmest conditions on land detected during the Pontevedra forest stage. Indeed, they occurred similarly during the MIS 9e plateau that characterizes the ice volume minimum of MIS 9. A record from the BlakeBahama Outer Ridge showed that within MIS 9, the Deep Western Boundary Current (DWBC) reached its deepest position during MIS 9e plateau (Yokokawa and Franz, 2002). As DWBC strength and position are related to the production rate of North Atlantic Deep Water (NADW), this reveals that the MIS 9 climatic optimum is probably linked to a strong North Atlantic meridional overturning circulation. However, in contrast, the difference in warmth between the warm periods of MIS 9 displayed by the Southern European pollen sequences is not always clearly recorded in the North Atlantic. On land, the Sanxenxo period appears clearly cooler than the Bueu interval and the SST during MIS 9a appears warmer than during most of the MIS 9c interval off Iberia but cooler in the subpolar North Atlantic. In the eastern equatorial and southwest Pacific, $\mathrm{Mg} / \mathrm{Ca}$ SST reconstructions suggest a warm phase during MIS 9a of at least $1^{\circ} \mathrm{C}$ warmer than during the interval from MIS 9d to 9b (Lea et al., 2000; Pahnke et al., 2003). Otherwise, in Antarctica, the deuterium records of Vostok or EPICA-Dome C ice cores show an important warm phase during substage $9 \mathrm{a}$ but not warmer than during substage 9c (Petit et al., 1999; EPICA members, 2004, Jouzel et al., 2007) (Fig. 5c). These comparisons demonstrate that the relative degree of climatic amelioration during the different MIS 9 warm periods appears strongly regional dependent. This remains, however, difficult to assess because of the seasonal character of the different paleotemperature proxies used and time resolution of the records. 


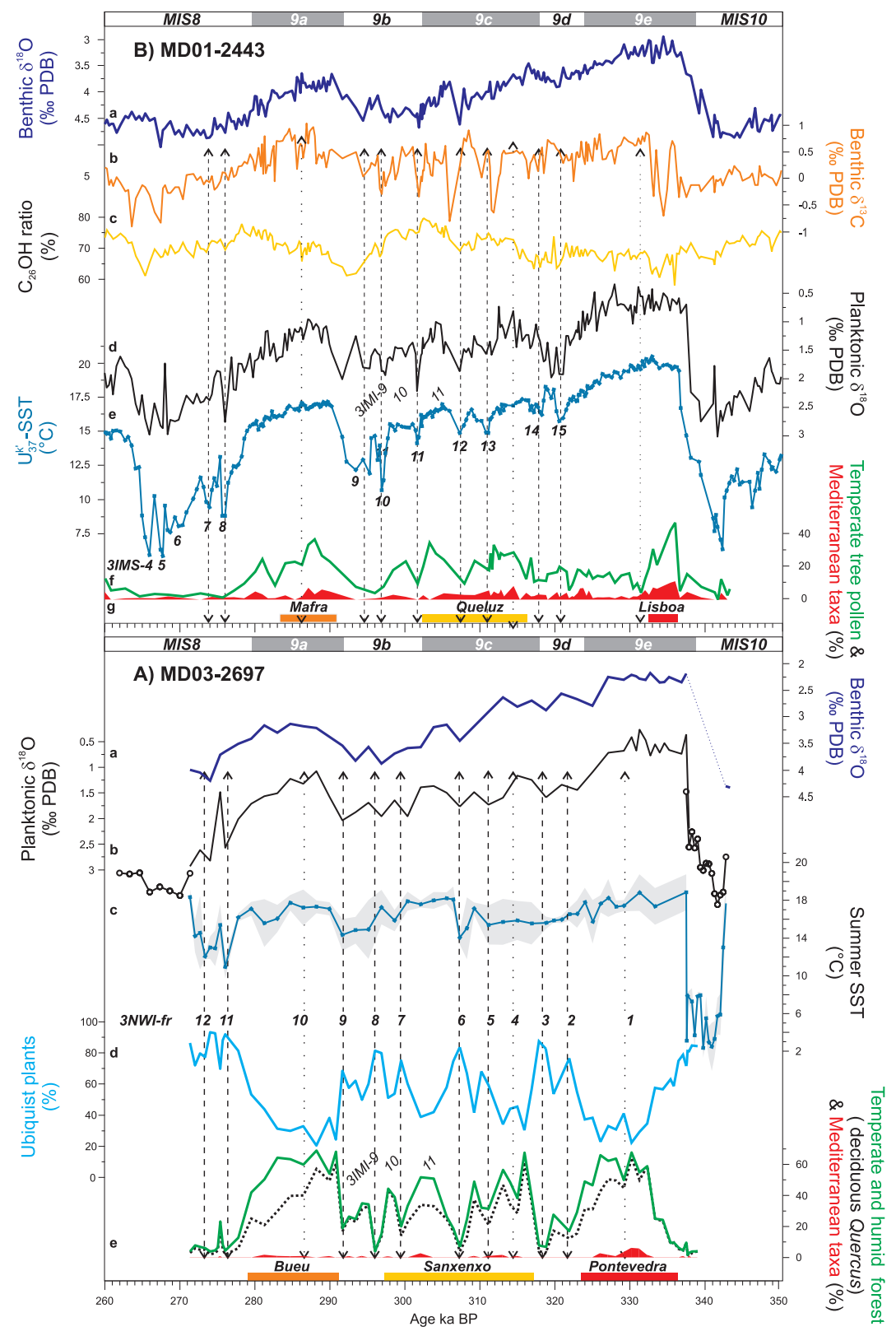

Fig. 4. Comparison of the Iberian margin sequences: MD03-2697 and MD01-2443. (A) Multi-proxy record from core MD03-2697 including from the top to the bottom: a) benthic $\delta^{18} \mathrm{O}$; b) planktonic $\delta^{18} \mathrm{O}$; c) summer SST derived from planktonic foraminifera assemblages (shaded area: SST estimation error); d) pollen percentages of ubiquist herbs; e) pollen percentages of the temperate and humid forest group (green line, including the taxa: deciduous Quercus (black dashed line), Alnus, Carpinus betulus, Corylus, Fagus, Quercus suber-type, Juglans, Pterocarya, Fraxinus excelsior-type, Platanus, Salix, Taxus, Tilia, Ulmus, Hedera, Buxus, Viburnum, Myrica, Daphne) and Mediterranean taxa (filled red). (B) Multiproxy record from the Southwestern Iberian margin core MD01-2443 (Tzedakis et al., 2004b; Martrat et al., 2007) including: a) benthic $\delta^{18} \mathrm{O}$; b) benthic $\delta^{13} \mathrm{C}$ (reflecting the relative influence of NADW and $\mathrm{AABW}$ at the site); c) $\mathrm{C}_{26} \mathrm{OH}$ ratio (ratio of vascular terrestrial plant compounds used as a proxy of deep-ocean ventilation); d) planktonic $\delta^{18} \mathrm{O}$; e) Uk'37-SST; f) pollen percentages of temperate tree (green) and g) pollen percentages of Mediterranean plants (red). Temperate tree pollen corresponds to the sum of Mediterranean and Eurosiberian taxa following Tzedakis et al. (2004b). Note that an offset of 0.64 per mil between MD01-2443 and MD03-2697 benthic $\delta{ }^{18} \mathrm{O}$ records is the result of the adjustment of the isotopic values to Uvigerina peregrina in the SW Iberian margin record while in core MD03-2697 isotopic measurements were performed on Cibicides wuellerstorfi. Marine isotope substages and forested intervals are shown by white and grey bands and colour bars, respectively. Dashed arrows underline cool/cold episodes; Iberian Margin Stadials (IMS) are indicating following Martrat et al. (2007). MD01-2443 data are plotted against their own chronologies originally described by Tzedakis et al. (2004b) and modified by Martrat et al. (2007). 

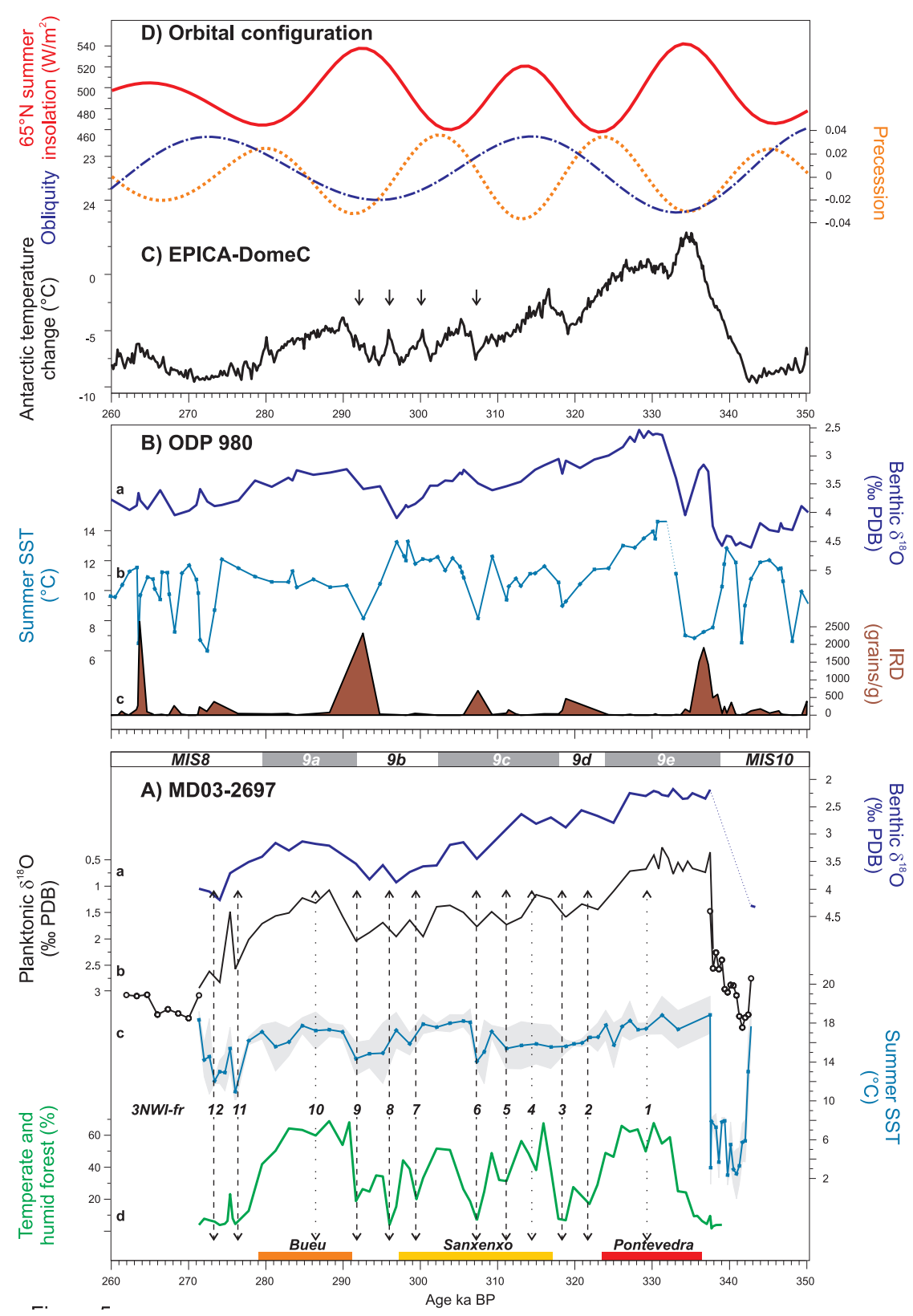

Fig. 5. (A) MIS 9 multiproxy record from the NW Iberian margin core MD03-2697 as shown in Fig. 4. (B) ODP site 980 record composed of a) benthic $\delta^{18} \mathrm{O}, \mathrm{b}$ ) summer SST derived from isotopic data; c) ice rafted detritus (McManus et al., 1999, 2001). A new chronology for the ODP site 980 interval presented in this figure was established by graphical correlation between the benthic $\delta^{18} \mathrm{O}$ curves of ODP 980 and MD03-2697 cores. (C) EPICA-Dome C temperature estimates from deuterium data on EDC3 timescale (Jouzel et al., 2007) (D) $65^{\circ} \mathrm{N}$ summer insolation $\left(\mathrm{W} / \mathrm{m}^{2}\right)$, obliquity and precession index (Berger, 1978).

Finally, the MIS 9 peak interglacial which is characterized by the highest $\mathrm{CO}_{2}$ concentration values of the last 650000 years, excluding the Holocene industrial period (Petit et al., 1999; Siegenthaler et al., 2005), does not really appear as the warmest period of the last seven climatic cycles. In NW Iberia, the forest expansion and the SST are not higher but probably comparable during the Pontevedra period than during the forest stages associated to MIS 5e, MIS $11 \mathrm{c}$ or
MIS 1 (Desprat et al., 2007). The ODP 980 record also displays quite similar SST values (less than $1^{\circ} \mathrm{C}$ estimation difference) during the MIS 1, 5e, 9e and 11c peak interglacials (McManus et al., 1999) while at the nearby site M23414, SST and planktic foraminiferal assemblages probably indicate colder conditions during MIS 9e (Kandiano and Bauch, 2003). 
5.2 MIS 9 millennial-scale climatic variability in the Iberian region

NW Iberian vegetation response to millennial-scale climatic variability is clearly recorded in the MD03-2697 marine pollen sequence. Suborbital cool/cold events are expressed by abrupt forest reductions of moderate to high amplitude (events 3NWI-fr1 to fr12, Fig. 3). MD03-2697 planktonic $\delta^{18} \mathrm{O}$ and summer SST estimates show cold conditions during the forest reduction events of MIS $9 \mathrm{~d}$ and MIS $9 \mathrm{~b}$ and a synchronous strong SST and forest decrease associated with events 3NWI-fr6, fr11 and 12 (Fig. 3). Unfortunately, for most of the events detected by the pollen record, the lower resolution analysis of the marine proxies in core MD03-2697 prevents us from identifying a SST change counterpart. Actually, the SW Iberian margin records from core MD01-2443 including alkenone-SST and pollen data (Fig. 4b; Tzedakis et al., 2004b; Martrat et al., 2007) show also a pronounced pattern of suborbital variability during the studied period. We will compare our data with the MD01-2443 records to examine the regional continental and marine character of the millennial-scale climatic variability detected in the NW Iberian region. Although the core MD03-2697 chronology is based on core MD01-2443 age-scale, NW Iberian vegetation and SST suborbital changes do not always appear synchronous with those of SW Iberian region. However, such abrupt events during the last glacial period and MIS 5 have been related with rapid shifts in the polar front and considered simultaneous in Eastern North Atlantic and in Southern Europe (Tzedakis, 2005, Shackleton et al., 2000; Sánchez Goñi et al., 2005, 2008). A certain degree of age uncertainty in our chronology is the result of the graphical correlation of the isotopic signals that are of different time resolution, and because of likely different changes in sediment accumulation rate at each site. The close location of the sites allows us to assume the synchroneity of the abrupt events even if their timing seems slightly different.

5.2.1 Sequence of terrestrial and marine abrupt events in the Iberian region

During the Pontevedra period, a forest reduction event (3NWI-fr1) is recorded at $\sim 329 \mathrm{ka}$ within the MIS $9 \mathrm{e}$ plateau. This event marks the end of maximal extent of the deciduous oak forest and Mediterranean plants and therefore the end of the climatic optimum in NW Iberia. In SW Iberia (Fig. 4b), an abrupt arid/cold event occurring at $\sim 332 \mathrm{ka}$ brought to an end the Lisboa forest stage while it led to a forest decline in France (Praclaux sequence) and Greece (Tenaghi Philippon) (Tzedakis et al., 2004b). The 3000 age discrepancy between SW and NW Iberia for this event is probably an artefact of the age model of our record which is not well constrained over this time period. Like in France and Greece, the forest recovered in Galicia afterwards and cooler temperate tree taxa such as Taxus developed while deciduous oak forest continued declining until the end of the Pontevedra period. Even though such an event is not present in the SW and NW Iberian margin SST records, both direct land-sea correlations show that a cooling trend follows the SST optimum values (Fig. 4). Consequently, this suborbital event not only marks the end of the forest stage in SW Iberia (Tzedakis et al., 2004b) but also the end of the climatic condition optimum in and off Iberia several millennia before the end of the ice volume minimum.

During the open forest interval between the Pontevedra and Sanxenxo, two temperate and humid forest minima (3NWI-fr2 and fr3) are detected in NW Iberia while two SST cooling events (3IMS-15 and 14) occurred off SW Iberia. In the SW Iberian margin pollen record, the cooling event 3IMS-14 is synchronous with a forest reduction but not the 3IMS-15 cooling. However, at the same time, Ericaceae are replaced by Poaceae in the herbaceous community which would reveal cooler or drier conditions (Roucoux et al., 2006).

Except of the first event (3NWI-fr4) which occurred during the MIS 9c ice volume minima, all the NW Iberian forest decreases within the Sanxenxo period have a counterpart in the SW Iberian margin SST and pollen records within the chronology uncertainties. 3NWI-fr5, fr6, fr7 events correlate with 3IMS-13, 12 and 11 cooling events, respectively.

Between the Sanxenxo and Bueu periods, forest reductions 3NWI-fr8 and fr9 also correspond to SST cooling off SW Iberia (3IMS- 10 and 9). Forest extent in SW Iberia is strongly reduced at the end of MIS $9 \mathrm{~b}$ but the time resolution of the MD01-2443 pollen record appears to be too low for indentifying individual vegetation responses to the cold oscillations 3IMS- 10 and 9.

During the Bueu forest stage, the event 3NWI-fr10 that occurs during the MIS 9a ice volume minimum also corresponds to a forest reduction in SW Iberia, but no change in the alkenone-SST signal is observed.

Later synchronous vegetation and SST changes in the NW Iberian region (3NWI-fr11 and fr12) are detected during the MIS 9a-8 transition while ice volume is already large. These two severe forest collapses correspond to strong SST decreases off SW Iberia (3IMS-8 and 7).

Therefore, the recurrent millennial-scale forest changes detected in NW Iberia actually testify to abrupt climatic changes that influenced the vegetation and the sea surface conditions in the mid-latitudes of the Eastern North Atlantic region, even though no SST reversals correspond to the terrestrial events during the ice volume minima of MIS 9e, 9c and $9 \mathrm{a}$.

5.2.2 Degree of the abrupt climatic changes: comparison between NW and SW Iberia

The character of the forest reductions in NW Iberia in terms of amplitude of change and forest extent minima is clearly variable and gives evidence of differential vigour of the 
abrupt climatic changes in this region. Events 3NWI-fr3, fr6, fr8, fr11 and 12 stand out by the collapse of the NW Iberian forest. They indicate that the most severe cooling episodes in this region occurred during substages $9 \mathrm{~d}, 9 \mathrm{~b}$ as well as $9 \mathrm{c}$ and at the end of the MIS 9a-8 transition.

Similarly to NW Iberian vegetation changes, the SW Iberian forest is also strongly reduced during the events 3NWI-fr3, fr6, fr8, fr11 and 12 along with SST decreases. However, during the events 3NWI-fr3 and fr6, recorded as severe cooling in NW Iberia, the relative contribution of steppe plants in the SW Iberian vegetation is small and temperate tree representation is moderately low, which imply less arid and cold conditions on land (Roucoux et al., 2006). In the ocean, the SST decreases also appear moderate off Southern Portugal during 3IMS-14 and 12 (Martrat et al., 2007). The SW Iberian record does not possibly capture the whole range of the 3IMS-12 event because of a lower time resolution around this episode, but the apparent contrasting climatic pattern between NW and SW Iberia during 3NWIfr3 needs further discussion. Records at higher latitudes show a strong cooling during MIS $9 \mathrm{~d}$ as in NW Iberia. In particular, an open vegetation interval is recorded in France (Reille et al., 1995) while a SST cooling of relatively high magnitude though not extreme is traced in the subpolar North Atlantic (McManus et al., 1999) (Fig. 5b). The difference in the magnitude of vegetation and SST changes between the northernmost sites and the SW Iberian ones may reflect the occurrence of a latitudinal temperature gradient during MIS 9d. Climatic deterioration, in particular in winter, could have been stronger in NW Iberia and France during this interval, because the ecological threshold of the temperate trees has been crossed at these northernmost sites and not in SW Iberia. Indeed, at sites where temperate trees are living near their critical tolerance limit, even a moderate climatic change can generate a forest collapse, which consequently impedes us to decipher the intensity of different cold events from the pollen diagrams (Tzedakis et al., 2004a). Therefore, the 3 NWI-fr3 cooling event in NW Iberia could have been moderate or at least less intense than 3NWI-fr6 or fr8, for instance. In addition, a certain degree of moisture availability, which is an important controlling factor of the vegetation in the Mediterranean region, could have allowed maintaining the temperate forest in SW Iberia during this event.

In contrast, the forest reductions 3 NWI-fr1, fr4 and 10, which punctuated the forested intervals Pontevedra, Sanxenxo and Bueu, are of small amplitude in NW Iberia and forest extent remained high during these events. Indeed, these episodes are in general characterized by a weak opening of the temperate and humid forest in favour of Ericacae but steppe plants and Poaceae did not expand. This vegetational change indicates weak cooling events with probably no humidity alteration in the northern peninsula. These slight climatic changes occurred interestingly during the ice volume minima of MIS 9e, 9c and 9a. In addition, none of them is associated with alkenone-SST oscillations in the
SW Iberian region. This suggests that the climatic changes are dampened during low ice volume conditions. Surprisingly, during the 3NWI-fr1 event within MIS 9e, the SW Iberian pollen record displays a pronounced decline of the tree populations in favour of Compositae Liguliflorae and steppe plants. According to Roucoux et al. (2006), this vegetation change would indicate a pronounced cooling and aridification in SW Iberia. However, the temperature and the precipitation change cannot be easily deciphered from the SW Iberian pollen record. In the light of the northernmost pollen records (MD03-2697 and Praclaux) showing both a weak forest reduction, and in the lack of a SST reversal off Iberia, a weak cooling at the most appears likely but it cannot account for the SW Iberian forest collapse. Taking into account that aridity is one major limiting factor for tree growth in the Mediterranean region, a weak cooling associated with strong moisture deficiency in winter seems a more parsimonious explanation for the vegetation change observed in this region.

Finally, the other events 3NWI-fr2, fr5, fr7 and fr9 mark a strong to moderate forest extent reduction but not a forest collapse. They reveal cooling episodes of intermediate strength in NW Iberia and are in general associated with moderate SST decreases $\left(\sim 2^{\circ} \mathrm{C}\right)$ off SW Iberia.

The NW Iberian pollen record not only allows us to document vegetation changes during MIS 9 in this region but to refine and characterize the sequence of suborbital climatic events previously identified by the SW Iberian margin SST record. More importantly, this highlights the persistence of millennial-scale climatic variability in Southern Europe throughout MIS 9 which appears coupled with North Atlantic SST changes. Effectively, suborbital climatic changes, namely cooling events, during MIS 9 happened whatever the ice volume extent but during low ice volume conditions the climatic oscillations seem dampened (cf. events 3NWI-fr1 fr4 and fr10) and somehow scarcer as far as the available records can tell.

\subsection{Climatic implications of the MIS 9 millennial-scale variability}

\subsubsection{Suborbital climatic variability versus ice volume minimum}

Suborbital variability during ice volume minimum is not a special feature of MIS 9e. Millennial variability represented by North Atlantic surface cooling and ice-rafting episodes as well as vegetation changes in adjacent landmasses appears to be also a characteristic of Holocene records (Bond et al., 1997; Came et al., 2007; Viau et al., 2002). Within the MIS 5e ice volume minimum, several suborbital SST cooling events are detected in the subpolar North Atlantic and Nordic Seas and one of them terminated the short-lived climatic optimum of the substage (Cortijo et al., 1994; Fronval and Jansen, 1997; Oppo et al., 2001, 2007). At the Grande Pile 
site (France), a series of cooling episodes are detected during the Eemian and have been suggested to be possibly related to the oceanic circulation changes in the Nordic seas and North Atlantic (Rousseau et al., 2006). In the Iberian Peninsula, a deciduous forest reduction might also be associated to the suborbital event marking the end of the MIS 5e climatic optimum in the North Atlantic. Indeed, before the substantial winter temperature decrease, which is clearly indicated by the development of Carpinus betulus in NW and SW Iberian margin sequences, a temperate forest minimum (mainly deciduous oak) occurred in SW Iberia at $\sim 123-122 \mathrm{ka}$ while the deciduous oak forest in NW Iberia was reduced (Fig. 4 from Sánchez Goñi et al, 2005). According to the pollen assemblages, the drier or cooler nature of the suborbital event causing the forest reduction in SW Iberia appears difficult to determine. However, this suborbital vegetation change seems to be concurrent with the beginning of the SST decrease off Iberia during MIS 5e (Sánchez Goñi et al., 2005). Similarly, the suborbital event during MIS 9e is coeval with the end of the SST optimum. In the subpolar North Atlantic, SST cooling events during MIS 5e ice volume minimum are marked by a reduction in MOC (Meridional Overturning Circulation) and minor ice-rafting events (Oppo et al., 2007). The MD012443 hydrological indicator records (Fig. 4b; Martrat et al., 2007) do not reveal, however, significant changes in deepocean circulation associated with the suborbital oscillations recorded in sea and air surface temperatures during MIS 9e. Sites which are highly sensitive to changes in MOC such as the ODP site 980 in the subpolar North Atlantic have to be analyzed in order to document the frequency and amplitude of MOC changes during MIS 9. Finally, the SW Iberian forest collapsed in response to an abrupt arid/cold event during the MIS 7e ice volume minimum (Tzedakis et al., 2004b).

Bond et al. (2001) interpreted the Holocene millennial variability as the result of atmospheric circulation changes forced by solar irradiance variability and put forward that solar-forced millennial-scale variability is a persistent feature of the past interglacials. The MIS 9e suborbital event could be the particular expression of such variability. However, there is no consensus on the forcing mechanisms for millennial climatic changes during interglacial periods; in particular the solar origin has been lately challenged by a Holocene subpolar North Atlantic record (Came et al., 2007).

Regardless of the origin, suborbital events within the MIS 9e ice volume minimum, but also those occurring during MIS 7e and MIS 5e, strikingly mark the premature end of the interglacial climatic optimum in Southern Europe and off Iberia. In addition, these events appear coeval with the abrupt declines in methane concentrations recorded in the Vostok ice core, indicating evidence of a global modification in climate conditions (Tzedakis et al., 2004b). Tzedakis et al. (2004b) introduced the challenging idea that the duration of interglacial periods may be dictated by millennial-scale variability. The new records presented here suggest, however, that suborbital variability would determine the duration of the climatic optimum of the interglacial period. The observed marine and terrestrial cooling trend following the interglacial climatic optimum is generally considered as a response to the orbital forcing and associated feedback mechanisms, further initiating the glacial inception (Crucifix and Loutre, 2002; Kageyama et al., 2004). We can wonder to which extent the millennial-scale climatic variability and the astronomical forcing each played a role in the duration of the interglacial climatic optimum, the interglacial demise and further the glacial inception.

\subsubsection{Possible factors modulating the millennial climatic changes}

Of particular interest is the climatic variability during the 30000 years following the interglacial period, which is characterized by frequent moderate to high amplitude vegetation and SST oscillations with recurrence time varying between 3 to $5 \mathrm{kyr}$ even during the forest stage Sanxenxo. The variability of this interval from MIS $9 \mathrm{~d}$ to $9 \mathrm{~b}$ is even more outstanding when we look at the other interglacial complexes of the last $500 \mathrm{ka}$. Large amplitude suborbital oscillations affect also the course of MIS 11 (Desprat et al., 2005; Oppo et al., 1998) as well as MIS 5 in North Atlantic from the subtropics to the subpolar region and adjacent landmasses (Chapman and Shackleton, 1999; Dansgaard et al., 1993; Heusser and Oppo, 2003; Lehman et al., 2002; McManus et al., 1994, 2002; Kukla et al., 1997; Oppo et al., 2007; Sánchez Goñi et al., 2005). However, forest intervals of the other climatic cycles from Iberian records (Desprat et al., 2006, 2007; Martrat et al., 2007; Roucoux et al., 2006; Sánchez Goñi et al., 1999, 2005) do not present oscillations with such recurrence and amplitude as the Sanxenxo period. For example, the apparent higher stability of temperatures on land and in the ocean during the terrestrial equivalent of MIS 7c, or at least the smaller magnitude of the forest changes in SW Iberia (Desprat et al., 2006; Martrat et al., 2007) are in clear contrast to the climatic variability during the Sanxenxo stage. Insolation variations discriminate Sanxenxo from other forest intervals by a relatively low $65^{\circ} \mathrm{N}$ summer insolation forcing (Fig. 5d), which probably played a role in the relatively low forest extent of this period by conditioning the climate regime (Tzedakis et al., 2003). However, there is no obvious direct relationship between the amplitude of the suborbital vegetation response and the magnitude of orbital parameter variations. For instance, the most severe cooling episodes in NW Iberia during MIS 9 (3NWI-fr3, fr6 and fr8) occur during intervals of both high and low summer insolation (Fig. 5).

A likely explanation for the particular high variability during MIS 9 is related to changes in oceanic circulation and ice-sheet size variations. Martrat et al. (2007) have shown that during the last $420 \mathrm{ka}$, prominent abrupt SST drops in the SW Iberian margin region, which occur during periods of increased ice-sheet extent, are preceded by decreases in both the $\mathrm{C}_{26} \mathrm{OH}$ ratio and benthic $\delta^{13} \mathrm{C}$, which indicate increasing 
deep water ventilation by AABW (Antarctic Bottom Water) inflow at the Iberian margin and a reduction of the NADW contribution (Martrat et al., 2007). Such prominent SST drops during the studied interval are represented by 3IMS7, 8, 9 and 10. The MD01-2443 data, Fig. 4b; Martrat et al., 2007) also suggest the likelihood of deep water circulation changes in connection with terrestrial and marine cooling events of moderate amplitude during the interval MIS 9d to $9 \mathrm{~b}$. Small decreases in the MD01-2443 benthic $\delta^{13} \mathrm{C}$ that would reveal a minor weakening of the NADW occur during 3IMS- 15 and 14 cooling episodes. Later, in a context of low deep water oxygenation (high $\mathrm{C}_{26} \mathrm{OH}$ ratio), sharp benthic $\delta^{13} \mathrm{C}$ declines with small $\mathrm{C}_{26} \mathrm{OH}$ ratio decreases are associated with the moderate SST cooling events 3IMS-12 and 11. Despite its low time resolution, the ODP site 980 record confirms a reduction in MOC during MIS 9d and $9 \mathrm{~b}$ and during a suborbital SST change at $\sim 307 \mathrm{ka}$ that probably corresponds to the event 3IMS-12 (Fig. 5b; McManus et al., 1999). Consequently, the climate variability detected at the Iberian margin and in the borderlands is likely to be linked to the recurrent reduction of the northward oceanic heat transport associated with a change in North Atlantic circulation and European atmospheric gradients. Atlantic MOC changes, whether caused by internal oscillations, ocean-atmosphere mechanisms or solar forcing, are generally involved as driver or amplifier of the millennial-scale climatic variability (Bond et al., 1997; Broecker et al., 1990; McManus et al., 2004; Mayewski et al., 1997; Sakai and Peltier, 1997).

McManus et al. (1999) and Schulz et al. (1999) showed a control of ice volume of the amplitude of SST millennialscale climatic variability. When ice sheets decay or grow, even in a limited extent during stadials, and ice volume surpasses a critical threshold ( $\sim 30 \mathrm{~m}$ sea level equivalent, 3.5 per mil benthic $\delta^{18} \mathrm{O}$ value), suborbital SST decreases of larger amplitude occur in association with abundant iceberg discharges which amplify in turn the reduction in MOC (McManus et al., 1999). A similar mechanism has been proposed for explaining the large amplitude suborbital climatic instabilities during MIS 5 and 11 (Chapman and Shackleton, 1999; Oppo et al., 1998, 2007). The benthic $\delta^{18} \mathrm{O}$ signals of the different North Atlantic records suggest a first weak ice-sheet enlargement during MIS 9d, but they do not reach the 3.5 per mil threshold (Figs. 4 and 5). However, the ODP 980 IRD record testifies of iceberg discharges in the North Atlantic (Fig. 5b) and severe cooling is experienced in the NW Iberian region during this interval. Glacier nucleation near surrounding coasts may have favoured ice margins to reach the sea, and therefore generation of iceberg discharges despite a relatively weak ice-sheet development (McManus et al., 1994). After a short-lived ice volume minimum during MIS 9c, ice sheet growth appears to begin early during the Sanxenxo period and the benthic $\delta^{18} \mathrm{O}$ values cross the 3.5 per mil threshold as early as $\sim 312 \mathrm{ka}$, i.e. just before the first high amplitude cold event of MIS 9c (3NWI-fr5, 3IMS-13), and until $\sim 290 \mathrm{ka}$ and again during the MIS 9a-8 transition (Figs. 4 and 5). This suggests that the ice-sheets are favourable to instabilities over most of the interval MIS 9c-9b. The ODP 980 IRD record testifies of important ice-rafting episodes during MIS 9b (3IMS-9 and 10) and MIS 9c (3IMS-12). However, bottom temperature variations can have a substantial influence on benthic $\delta^{18} \mathrm{O}$ signal (Skinner and Shackleton, 2006), which consequently may not strictly represent ice volume variations.

A number of sea level reconstruction based on different approaches are available for the previous climatic cycles but for MIS 9 they significantly diverge, in particular for the amplitude of sea level drop and rise during MIS 9d and 9c, respectively (Bintanja et al., 2005; Lea et al., 2002; McManus et al., 1999; Siddall et al., 2003; Shackleton et al., 2000; Stirling et al., 2001; Waelbroeck et al., 2002). On the other hand, they broadly agree on the important sea level drop between the MIS 9c ice volume minimum and MIS 9b maximum, reaching glacial values similar to MIS 3 . With the lack of IRD evidence we cannot infer the amplification of MOC reduction by ice melting during each cooling event. However, it is noticeable that European vegetation and SST during MIS 9 particularly respond to millennial-scale variability when ice sheets were decaying or when they were building up and reached a significant size (cf. 3.5 per mil threshold). Moreover, even if ice-rafting events do not actually accompany some cold events, modeling experiments suggest that the overturning circulation in the North Atlantic is more oscillatory when freshwater discharge is moderate, as might occur during periods of ice growth (Sakai and Peltier, 1997).

\subsection{Similar millennial-scale variability during MIS 3 and MIS 9?}

Identifying intervals which display similar rapid climatic changes even though boundary conditions are divergent, is a helpful approach to decipher the potential mechanisms controlling the amplitude and frequency of the millennial-scale variability. The last glacial period is well-known for its millennial-scale dramatic climatic oscillations which have been first identified in the temperature records of Greenland ice cores (Dansgaard et al., 1993; Grootes et al., 1993) and later on in numerous marine or continental paleoclimate records (Bond et al., 1993; Bond and Lotti, 1995; Grimm et al., 2006; Allen et al., 1999; Sanchez Goñi et al., 2000). Recently, Siddall et al. (2007) have shown that millennial-scale variability is strikingly similar during the 290-310 kyr MIS 9 interval (designated as MIS 8.6 section in their paper) and the $\sim 30-55$ kyr MIS 3 interval. The frequency (in terms of "Bond cycles") and amplitude of the millennial changes from both intervals are similar according to a comparison between the MIS 3 and MIS 9 deuterium and methane profiles from Vostok ice core as well as between the MIS 9 model-estimated Greenland temperatures and GISP $\delta^{18} \mathrm{O}$ (Siddall et al., 2007). However, the putative similarity between the MIS 3 and MIS 9 millennial variabilities in the 


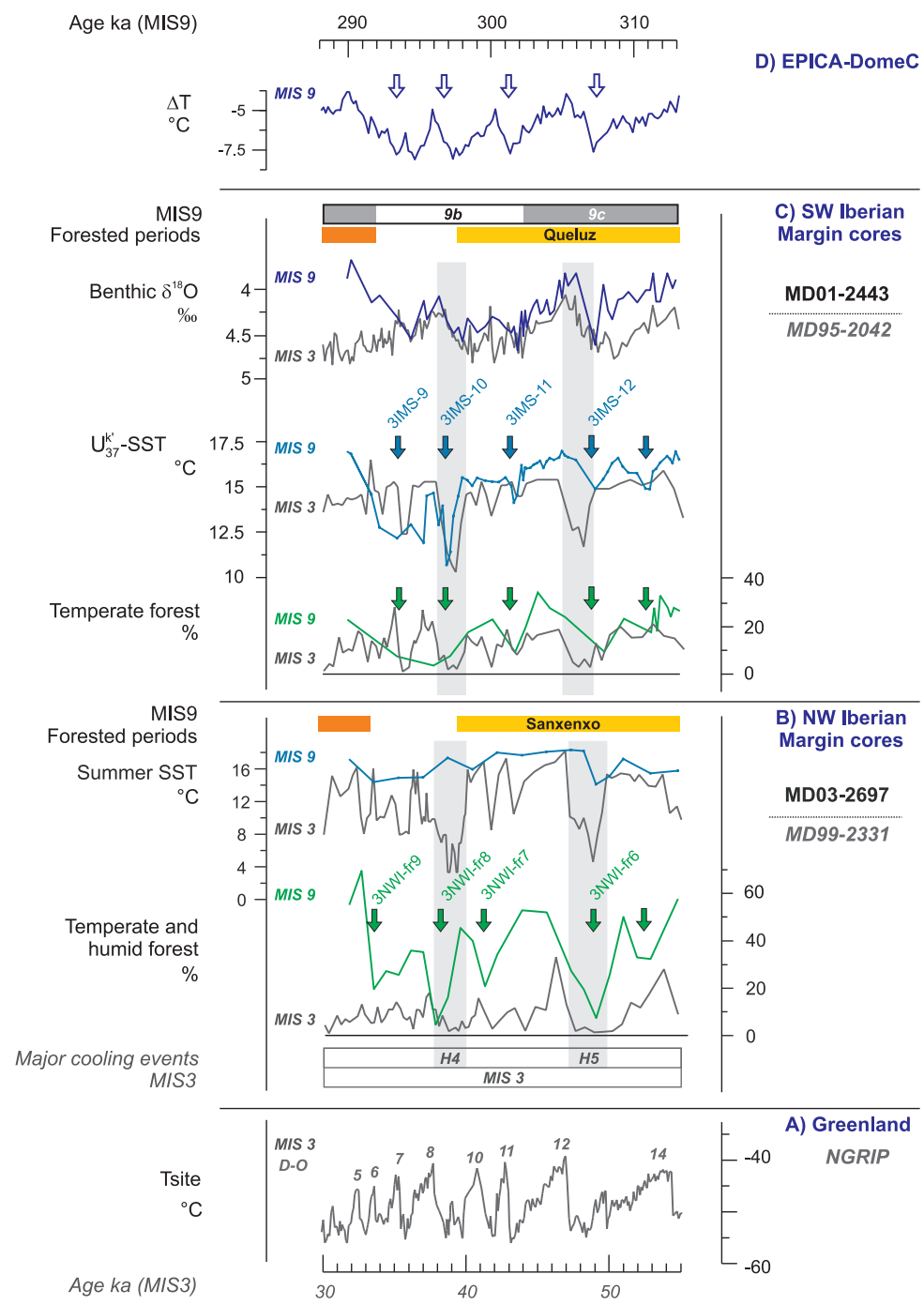

Fig. 6. Comparison of the abrupt climatic variability during MIS 3 and MIS 9. MIS 3 marine and terrestrial records (shown in Figs. 3 and 4 from Sánchez Goñi et al., 2008) are presented in grey while data from the time period 313-290 ka are in blue or green. From the bottom to the top: (A) NGRIP: MIS 3 Greenland temperature curve (Tsite in ${ }^{\circ} \mathrm{C}$ ) (Hubert et al., 2006; Sánchez Goñi et al., 2008); (B) NW Iberian margin cores (MIS 3 from MD99-2331 (Sánchez Goñi et al., 2008) and 313-290 ka interval from MD03-2697, this study): temperate and humid forest pollen percentages and planktic foraminifera-derived summer SST $\left({ }^{\circ} \mathrm{C}\right.$ ); (C) SW Iberian margin cores (MIS 3 from MD95-2042, Sánchez Goñi et al., 2000; Pailler and Bard, 2002; Shackleton et al., 2000, and 313-290 ka interval from MD01-2443, Tzedakis et al., 2004b; Martrat et al., 2007): Temperate tree pollen percentages, alkenone-derived (U $\left.{ }_{37}^{k^{\prime}}\right)$ SST in ${ }^{\circ} \mathrm{C}$ and benthic $\delta^{18} \mathrm{O}(\%$ ); (D) EPICA-Dome C temperature estimates $\left({ }^{\circ} \mathrm{C}\right)$ from deuterium data on EDC3 timescale (Jouzel et al., 2007). Forest stages, NW Iberian forest reduction events and Iberian Margin Stadial are indicated on the MIS 9 records as shown in Fig. 5. D-O events are numbered on the NGRIP record and grey bars show the major cooling events associated with Heinrich events $\left(\mathrm{H}_{3}\right.$ and $\left.\mathrm{H}_{4}\right)$ recorded in the MIS 3 Iberian margin sequences.

Northern Hemisphere needs to be tested using actual highresolution paleorecords such as those of the Iberian margin which offer vegetation and SST records for both time periods. In the Iberian region, the recurrence time of the suborbital changes over this MIS 9 interval accordingly recalls the MIS 3 glacial variability in terms of Dansgaard-Oeschger cycles or groups of them. Between 310 and $290 \mathrm{ka}$, four Antarctic isotopic maxima (warm events) are recorded in the Vostok, EPICA - Dome C or Dome Fuji Antarctic ice cores (Petit et al., 1999, EPICA community members, 2004; Kawamura, 2007) while four cold events are shown by the Iberian vegetation and SST records (3NWI-fr6, fr7, fr8, fr9 in core MD03-2697; 3IMS-12, 11, 10 and 9 in core MD012443) (Fig. 6). The similarity between the amplitude of SST cooling events during both intervals of MIS 3 and MIS 9 (Martrat et al., 2007) also seems relevant in SW Iberia. However, a higher resolution record of NW Iberian SST is necessary to reach such a conclusion. In contrast, the amplitude 
of the forest reductions in SW Iberia and in particular in NW Iberia appears larger during this MIS 9 interval than during MIS 3 (Fig. 6). However, firstly, a similar forest collapse in Iberia can occur in response to cooling events of different severity. Forest change records in Iberia do not always capture the full range of climate change due to the tolerance threshold of the temperate trees to cold conditions (Tzedakis et al., 2004a). Indeed, the difference of cooling between D-O stadials and Heinrich events during the last glacial period is not always detected by the Iberian vegetation record although it is evident at other Southern European sites (Sánchez Goñi et al., 2000, 2002; Tzedakis et al., 2004a). Assessment of the cooling difference between MIS 3 and MIS 9 stadials is hardly feasible from the Iberian pollen records. Secondly, after the pollen sequences and SW Iberian margin SST estimates, forest extent and interstadial SST were larger and warmer, respectively, during most of the Sanxenxo interval than during MIS 3 (10-20\% higher temperate and humid forest and 1 to $3^{\circ} \mathrm{C}$ warmer SST) (Martrat et al., 2007, Sánchez Goñi et al., 2000, 2008). Therefore, the Iberian vegetation records show stronger amplitude of climatic changes on land during MIS 9 in comparison to those of MIS 3, probably due to the larger expansion of the temperate and humid forest in between the cooling events during MIS 9. In any case, the Iberian margin records confirm that high amplitude multi-millennial climatic oscillations which are likely associated with deep-ocean circulation changes, occurred in the Northern Hemisphere during the interval 290-310 kyr as predicted by the modelled Greenland $\delta^{18} \mathrm{O}$ from the reverse seesaw calculation (Siddall et al., 2007) and the methane Vostok record (Delmotte et al., 2004). As a different astronomical forcing but a similar range of sea level marks the MIS 9b and MIS 3 intervals, Siddall et al. (2007) proposed that ice volume, in particular through the existence of floating ice shelves at the northern ice-sheet margins, is a key factor to predisposition the Earth climate system to the millennialscale variability. In turn, Earth's orbital forcing would play an indirect role in governing the ice-sheet configuration (Siddall et al., 2007). Additionally, $\mathrm{CO}_{2}$ concentrations reach the same range during MIS 9b and MIS 3 (Petit et al., 1999; Indermühle et al., 2000). Greenhouse gases (primarily $\mathrm{CO}_{2}$ ) and secondary albedo, mainly from northern ice-sheet brightness, which are considered as the major feedbacks on ice volume (Ruddiman, 2006), must also be a key factor, at least, in setting favourable ice volume conditions to millennial-scale variability. Consequently, the similarity of the suborbital change pattern in the SST records and likely in the vegetation records from the Iberian margin between MIS 3 and the MIS 9 interval $310-290 \mathrm{kyr}$ reinforces the potential role of the ice volume amount and ice-sheet configuration in modulating the millennial-scale variability. However, as suborbital variability seems to be a pervasive feature of glacial as well as interglacial periods, ice volume state does not explain its origin (Oppo, 1997).

\section{Conclusions}

The new marine pollen record MD03-2697 retrieved from the NW Iberian margin provides a detailed reconstruction of the vegetation changes during MIS 9 in the adjacent landmass. As shown by the other long European pollen records, the vegetation response in NW Iberia to orbital-scale climatic variability is represented by three forest stages of different extent, indicating a short-lived climatic optimum on land coeval with SST maximum in the mid-latitudes of the eastern North Atlantic ocean during the MIS 9e ice volume minimum, and a second forested interval of moderate warming. More importantly, this sequence gives a detailed picture of the vegetation response to millennial-scale climatic variability in NW Iberia. The comparison with the southern Iberian margin pollen, SST and hydrological indicator records allowed us to refine and characterize the millennial-scale variability in the Iberian region during this stage. Moreover, the MD01-2443 record (Martrat et al., 2007) shows that the suborbital cold events of high to moderate amplitude detected on land and in the ocean are likely related to changes in deep-water circulation, and an amplification of the reduction in MOC by iceberg discharges is probable at least during MIS 9d, the midMIS 9c cold event and MIS 9b. However, improving the resolution of the sensitive subpolar North Atlantic site ODP 980 is necessary to assess more accurately the changes in MOC and the ice-rafting episodes related to suborbital cooling of MIS 9. Finally, our work provides additional evidence of the pervasive millennial-scale climatic variability in Southern Europe throughout past climatic cycles of the Late Pleistocene, regardless of glacial state. However, suborbital vegetation changes associated with SST changes appear more frequent and of higher amplitude during the 30000 years following the MIS 9e interglacial period and during the MIS 9a8 transition. As these intervals can be distinguish by an intermediate to high ice volume and are mainly periods of ice growth, this points at an indirect control of the ice volume on the expression of the millennial climatic change.

Acknowledgements. We thank the logistics and coring teams on board of the R/V Marion Dufresne during the PICABIA oceanographic cruise and M.-H. Castera, K. Charlier, O. Ther and F. Dewilde for laboratory assistance. We are also grateful to Pr N. J. Shackleton and L. de Abreu for sharing the isotopic data from core MD01-2443. We are thankful to L. Dupont and B. Martrat for their helpful review and to the CP editor A. Paul for his corrections. This research was supported by IPEV (Institut Paul Emile Victor), PNEDC (Programme National d'Etude de la Dynamique du Climat), the Gary Comer Science and Education Foundation and the US National Science Foundation (OCE grants 8-4911100 and 8-256500). This paper is Bordeaux 1 University, UMR-CNRS 5805 EPOC contribution $n^{\circ} 1720$.

Edited by: A. Paul 


\section{References}

Alcara Ariza, F., Asensi Marfil, A., de Bolos, O., Capdevilla, O., Costa Tales, M., Arco Aguilar, M., Diaz Gonzales, T. E., Diez Garretas, B., Fernandez Prieto, J. A., Fernandez Gonzales, F., Izco Sevillando, J., Loidi Arregui, J., Martinez Parras, J. M., Navarro Andres, F., Ninot I Sugranes, J. M., Peinado Lorca, M., Rivas Martinez, S., Sanchez Mata, D., Valle Guitierrez, C., Vigo I., Bonada, J., and Wildpret de la Torre, W.: La vegetación de España, Universidad de Alcala de Henares, Spain, 544 pp., 1987.

Allen, J. R. M., Brandt, U., Brauer, A., Hubberten, H.-W., Huntley, B., Keller, J., Kraml, M., Mackensen, A., Mingram, J., Negendank, J. F. W., Nowaczyk, N. R., Oberhänsli, H., Watts, W. A., Wulf, S., and Zolitschka, B.: Rapid environmental changes in southern Europe during the last glacial period, Nature, 400, 740743, doi:10.1038/23432, 1999.

Atlas Nacional de España: Climatologia, Ministerio de Obras Publicas y Transportes, Direccion General del Instituto Geografico Nacional, Madrid, Spain, 1992.

Berger, A. L.: Long-Term variations of daily insolation and Quaternary climatic changes, J. Atmos. Sci., 35, 2362-2367, 1978.

Bintanja, R., van de Wal, R. S. W., and Oerlemans, J.: Modelled atmospheric temperatures and global sea levels over the past million years, Nature, 437, 125-128, doi:10.1038/nature03975, 2005.

Bond, G., Broecker, W., Johnsen, S., McManus, J., Labeyrie, L., Jouzel, J., and Bonani, G.: Correlations between climate records from North Atlantic sediments and Greenland ice, Nature, 365, 143-147, doi:10.1038/365143a0, 1993.

Bond, G., Kromer, B., Beer, J., Muscheler, R., Evans, M. N., Showers, W., Hoffman, S., Lotti-Bond, R., Hajdas, I., and Bonani, G.: Persistent solar influence on North Atlantic climate during the Holocene, Science, 294, 2130-2136, doi:10.1126/science.1065680, 2001.

Bond, G. and Lotti, R.: Iceberg discharges into the North Atlantic on millennial time scales during the Last Glaciation, Science, 267, 1005-1009, doi:10.1126/science.267.5200.1005, 1995.

Bond, G., Showers, W., Cheseby, M., Lotti, R., Almasi, P., deMenocal, P., Priore, P., Cullen, H., Hajdas, I., and Bonani, G.: A pervasive millennial-scale cycle in North Atlantic Holocene and Glacial Climates, Science, 278, 1257-1266, doi:10.1126/science.278.5341.1257, 1997.

Broecker, W. S., Bond, G., Klas, M., Bonani, G., and Wolfli, W.: A salt oscillator in the glacial Atlantic?, 1. The concept, Paleoceanography, 5, 469-477, 1990.

Came, R. E., Oppo, D. W., and McManus, J. F.: Amplitude and timing of temperature and salinity variability in the subpolar North Atlantic over the past $10 \mathrm{k.y}$, Geology, 35, 315-318, 2007.

Chapman, M. R. and Shackelton, N. J.: Global ice-volume fluctuations, North Atlantic ice-rafted events, and deep-ocean circulation changes between 130 and 70 ka, Geology, 27, 795-798, 1999.

Cortijo, E., Duplessy, J.-C., Labeyrie, L., Leclaire, H., Duprat, J., and van Weering, T. C. E.: Eemian cooling in the Norwegian Sea and North Atlantic Ocean preceding continental ice-sheet growth, Nature, 372, 446-449, doi:10.1038/372446a0, 1994.

Crucifix, M. and Loutre, M. F.: Transient simulations over the last interglacial period (126-115 kyr BP): feedback and forcing analysis, Clim. Dynam., 19, 417-433, 2002.

Dansgaard, W., Johnsen, S. J., Clausen, H. B., Dahl-Jensen, D.,
Gundestrup, N. S., Hammer, C. U., Hvidberg, C. S., Steffensen, J. P., Sveinbjörnsdottir, A. E., Jouzel, J., and Bond, G.: Evidence for general instability of past climate from a 250-kyr ice-core record, Nature, 364, 218-220, doi:10.1038/364218a0, 1993.

de Vernal, A., Henry, M., and Bilodeau, G.: Techniques de préparation et d'analyse en micropaléontologie, Les cahiers du GEOTOP, 3, 16-27, 1996.

Delmotte, M., Chappellaz, J., Brook, E., Yiou, P., Barnola, J. M., Goujon, C., Raynaud, D., and Lipenkov, V. I.: Atmospheric methane during the last four glacial-interglacial cycles: Rapid changes and their link with Antarctic temperature, J. Geophys. Res., 109, D12104, doi:10.1029/2003JD004417, 2004.

Desprat, S.: Réponses climatiques marines et continentales du SudOuest de l'Europe lors des derniers interglaciaires et des entrées en glaciations, $\mathrm{PhD}$ thesis, Université Bordeaux I, France, 282 pp., 2005.

Desprat, S., Sanchez Goni, M. F., Naughton, F., Turon, J.-L., Duprat, J., Malaize, B., Cortijo, E., and Peypouquet, J.-P.: Climate variability of the last five isotopic interglacials: Direct land-sea-ice correlation from the multiproxy analysis of NorthWestern Iberian margin deep-sea cores, in: The Climate of Past Interglacials, Developments in Quaternary Science, edited by: Sirocko, F., Litt, T., Claussen, M., and Sánchez Goñi, M. F., Elsevier, 375-386, 2007.

Desprat, S., Sánchez Goñi, M. F., Turon, J.-L., Duprat, J., Malaizé, B., and Peypouquet, J.-P.: Climatic variability of Marine Isotope Stage 7: direct land-sea-ice correlation from a multiproxy analysis of a northwestern Iberian margin deep-sea core, Quaternary Sci. Rev., 25, 1010-1026, 2006.

Desprat, S., Sánchez Goñi, M. F., Turon, J.-L., McManus, J. F., Loutre, M. F., Duprat, J., Malaizé, B., Peyron, O., and Peypouquet, J.-P.: Is vegetation responsible for glacial inception during periods of muted insolation changes?, Quaternary Sci. Rev, 24, 1361-1374, 2005.

EPICA community members: Eight glacial cycles from an Antarctic ice core, Nature, 429, 623-628, doi:10.1038/nature02599, 2004.

Fronval, T. and Jansen, E.: Eemian and early Weichselian (140$60 \mathrm{ka})$ paleoceanography and paleoclimate in the Nordic seas with comparisons to Holocene conditions, Paleoceanography, 12, 443-462, 1997.

Grimm, E. C., Watts, W. A., Jacobson Jr., G. L., Hansen, B. C. S., Almquist, H., and Dieffenbacher-Krall, A. C.: Warm Wet Heinrich Events in Florida, Quaternary Sci. Rev., 25, 2197-2211, 2006.

Grootes, P. M., Stuiver, M., White, J. W. C., Johnsen, S., and Jouzel, J.: Comparison of oxygen isotope records from the GISP2 and GRIP Greenland ice cores, Nature, 366, 552-554, doi:10.1038/366552a0, 1993.

Heusser, L. E. and Balsam, W. L.: Pollen distribution in the N. E. Pacific Ocean, Quaternary Res., 7, 45-62, 1977.

Heusser, L. and Oppo, D.: Millennial- and orbital-scale climate variability in southeastern United States and in the subtropical Atlantic during Marine Isotope Stage 5: evidence from pollen and isotopes in ODP Site 1059, Earth Planet. Sc. Lett., 214, 483490, 2003.

Huber, C., Leuenberger, M., Spahni, R., Flückiger, J., Schwander, J., Stocker, T. F., Johnsen, S., Landais, A., and Jouzel, J.: Isotope calibrated Greenland temperature record over Marine Iso- 
tope Stage 3 and its relation to $\mathrm{CH} 4$, Earth Planet. Sc. Lett., 243, 504-519, 2006.

Indermühle, A., Monnin, E., Stauffer, B., Stocker, T. F., and Wahlen, M.: Atmospheric $\mathrm{CO}_{2}$ concentration from 60 to $20 \mathrm{kyr}$ BP from the Taylor Dome Ice Core, Antarctica, Geophys. Res. Lett., 27, 735-738, 2000.

Kageyama, M., Charbit, S., Ritz, C., Khodri, M., and Ramstein, G.: Quantifying ice-sheet feedbacks during the last glacial inception, Geophys. Res. Lett., 31, L24203, doi:10.1029/2004GL021339, 2004.

Kandiano, E. S. and Bauch, H. A.: Surface ocean temperatures in the Northeast Atlantic during the last 500000 years: Evidence from foraminiferal census data, Terra Nova, 4, 265-271, doi:10.1046/j.1365-3121.2003.00488.x, 2003.

Kawamura, K., Parrenin, F., Lisiecki, L., Uemura, R., Vimeux, F., Severinghaus, J. P., Hutterli, M. A., Nakazawa, T., Aoki, S., Jouzel, J., Raymo, M. E., Matsumoto, K., Nakata, H., Motoyama, H., Fujita, S., Goto-Azuma, K., Fujii, Y., and Watanabe, O.: Northern Hemisphere forcing of climatic cycles in Antarctica over the past 360000 years, Nature, 448, 912-916, doi:10.1038/nature06015, 2007.

Kukla, G., McManus, J. F., Rousseau, D.-D., and Chuine, I.: How long and how stable was the last interglacial?, Quaternary Rev., 16, 605-612, 1997.

Lea, D. W., Pak, D. K., Peterson, L. C., and Hughen, K. A.: Synchroneity of tropical high latitude Atlantic temperatures over the last glacial termination, Science, 301, 1361-1364, doi:10.1126/science.1088470, 2003.

Lea, D. W., Pak, D. K., and Spero, H. J.: Climate impact of the Late Quaternary Equatorial Pacific sea surface temperature variations, Science, 289, 1719-1724, doi:10.1126/science.289.5485.1719, 2000.

Lehman, S. J., Sachs, J. P., Crotwell, A. M., Keigwin, L. D., and Boyle, E. A.: Relation of subtropical Atlantic temperature, highlatitude ice rafting, deep water formation, and European climate 130000-60000 years ago, Quaternary Sci. Rev., 21, 1917-1924, 2002.

Martrat, B., Grimalt, J. O., Lopez-Martinez, C., Cacho, I., Sierro, F. J., Flores, J. A., Zahn, R., Canals, M., Curtis, J. H., and Hodell, D. A.: Abrupt temperature changes in the Western Mediterranean over the past 250000 years, Science, 306, 1762-1765, doi:10.1126/science.1101706, 2004.

Martrat, B., Grimalt, J. O., Shackleton, N. J., de Abreu, L., Hutterli, M. A., and Stocker, T. F.: Four climate cycles of recurring deep and surface water destabilizations on the Iberian margin, Science, 317, 502-507, doi:10.1126/science.1139994, 2007.

Mayewski, P. A., Meeker, L. D., Twickler, M. S., Whitlow, S. I., Yang, Q., Lyons, W. B., and Prentice, M.: Major features and forcing of high latitude northern hemisphere atmospheric circulation over the last 110000 years, J. Geophys. Res., 102, 2634526366, 1997.

McManus, J. F., Bond, G. C., Broecker, W. S., Johnsen, S., Labeyrie, L., and Higgins, S.: High-resolution climate records from the North Atlantic during the last interglacial, Nature, 371, 326-329, 1994

McManus, J. F., Francois, R., Gherardi, J.-M., Keigwin, L. D., and Brown-Leger, S.: Collapse and rapid resumption of Atlantic meridional circulation linked to deglacial climate changes, Nature, 428, 834-837, doi:10.1038/nature02494, 2004.
McManus, J. F., Oppo, D. W., and Cullen, J. L.: A 0.5million-year record of millennial-scale climate variability in the North Atlantic, Science, 283, 971-975, doi:10.1126/science.283.5404.971, 1999.

McManus, J. F., Oppo, D. W., and Cullen, J. L.: ODP 980 Isotope and IRD Data. IGBP PAGES/World Data Center A for Paleoclimatology, Data Contribution Series \#2001-065. NOAA/NGDC Paleoclimatology Program, Boulder, CO, USA, 2001.

McManus, J. F., Oppo, D. W., and Keigwin, L. D.: Thermohaline circulation and prolonged interglacial warmth in the North Atlantic, Quaternary Res., 58, 17-21, 2002.

Naughton, F.: As variações climáticas dos últimos 30000 anos e sua influência na evolução dos sistemas costeiros do norte de Portugal, $\mathrm{PhD}$ thesis, University of Lisbon, Portugal, 362 pp., 2007.

Naughton, F., Sanchez Goni, M. F., Desprat, S., Turon, J.-L., Duprat, J., Malaize, B., Joli, C., Cortijo, E., Drago, T., and Freitas, M. C.: Present-day and past (last 25000 years) marine pollen signal off western Iberia, Mar. Micropaleontol., 62, 91114, 2007.

Oppo, D. W.: Millennial climate oscillations, Science, 278, 1244 1246, doi:10.1126/science.278.5341.1244, 1997.

Oppo, D. W., Keigwin, L. D., and McManus, J. F.: Persistent suborbital climate variability in marine isotope stage 5 and Termination II, Paleoceanography, 16, 280-292, 2001.

Oppo, D. W., McManus, J. F., and Cullen, J. L.: Abrupt climate events 500000 to 340000 years ago: evidence from subpolar North Atlantic sediments, Science, 279, 1335-1338, doi:10.1126/science.279.5355.1335, 1998.

Oppo, D. W., McManus, J. F., and Cullen, J. L.: Evolution and demise of the Last Interglacial warmth in the subpolar North Atlantic, Quaternary Sci. Rev., 25, 3268-3277, 2006.

Ozenda, P.: Les végétaux dans la biosphère, Doin, Paris, France, 431 pp., 1982.

Pahnke, K., Zahn, R., Elderfield, H., and Schulz, M.: 340000-year centennial-scale marine record of Southern Hemisphere climatic oscillation, Science, 301, 948-952, doi:10.1126/science.1084451, 2003.

Pailler, D. and Bard, E.: High frequency palaeoceanographic changes during the past $140000 \mathrm{yr}$ recorded by the organic matter in sediments of the Iberian Margin, Palaeogeogr. Palaeocl., 181, 431-452, 2002.

Petit, J. R., Jouzel, J., Raynaud, D., Barkov, N. I., Barnola, J.M., Basile, I., Bender, M., Chappellaz, J., Davis, M., Delaygue, G., Delmotte, M., Kotyakov, V. M., Legrand, M., Lipenkov, V. Y., Lorius, C., Pépin, L., Ritz, C., Saltzman, E., and Stievenard, M.: Climate and atmospheric history of the past 420000 years from the Vostok ice core, Antarctica, Nature, 399, 429436, doi:10.1038/20859, 1999.

Pflaumann, U., Duprat, J., Pujol, C., and Labeyrie, L. D.: SIMMAX: A modern analog technique to deduce Atlantic sea surface temperatures from planktonic foraminifera in deep-sea sediments, Paleoceanography, 11, 15-35, 1996.

Prell, W. L., Imbrie, J., Martinson, D. G., Morley, J. J., Pisias, N. G., Shackleton, N. J., and Streeter, H. F.: Graphic correlation of oxygen isotope stratigraphy application to the late Quaternary, Paleoceanography, 1, 137-162, 1986.

Prentice, I. C., Bartlein, P. J., and Webb III, T.: Vegetation and climate change in eastern North America since the Last Glacial Maximum, Ecology, 72, 2038-2056, 1991. 
Reille, M. and de Beaulieu, J.-L.: Long Pleistocene pollen records from the Praclaux Crater, South-Central France, Quaternary Res., 44, 205-215, 1995.

Reille, M., de Beaulieu, J.-L., Svobodova, V., Andrieu-Ponel, V., and Goeury, C.: Pollen analytical biostratigraphy of the last five climatic cycles from a long continental sequence from the Velay region (Massif Central, France), J. Quaternary Sci., 15, 665-685, 2000.

Roucoux, K. H., de Abreu, L., Shackleton, N. J., and Tzedakis, P. C.: The response of NW Iberian vegetation to North Atlantic climate oscillations during the last $65 \mathrm{kyr}$, Quaternary Sci. Rev., 24, 1637-1653, 2005.

Roucoux, K. H., Tzedakis, P. C., de Abreu, L., and Shackleton, N. J.: Climate and vegetation changes 180000 to 345000 years ago recorded in a deep-sea core off Portugal, Earth Planet. Sc. Lett., 249, 307-325, 2006.

Rousseau, D. D., Hatté, C., Guiot, J., Duzer, D., Schevin, P., and Kukla, G.: Reconstruction of the Grande Pile Eemian using inverse modeling of biomes and $\delta^{13} \mathrm{C}$, Quaternary Sci. Rev., 25, 2806-2819, 2006.

Ruddiman, W. F.: Ice-driven $\mathrm{CO}_{2}$ feedback on ice volume, Clim. Past, 2, 43-55, 2006, http://www.clim-past.net/2/43/2006/.

Ruddiman, W. F.: The early anthropogenic hypothesis: Challenges and responses, Rev. Geophys., 45, RG4001, doi:10.1029/2006RG000207, 2007.

Sakai, K. and Peltier, W. R.: Dansgaard-Oeschger oscillations in a coupled atmosphere-ocean climate model, J. Climate, 10, 949970, 1997.

Sánchez Goñi, M. F., Eynaud, F., Turon, J.-L., and Gendreau, S.: European climatic response to millennial-scale climatic changes in the atmosphere-ocean system during the Last Glacial period, Quaternary Res., 54, 394-403, 2000.

Sánchez Goñi, M. F., Eynaud, F., Turon, J.-L., and Shackleton, N. J.: High resolution palynological record off the Iberian margin: direct land-sea correlation for the Last Interglacial complex, Earth Planet. Sc. Lett., 171, 123-137, 1999.

Sánchez Goñi, M. F., Landais, A., Fletcher, W., Naughton, F., Desprat, S., and Duprat, J.: Contrasting impacts of Dansgaard - Oeschger events over a western European latitudinal transect modulated by orbital parameters, Quaternary Sci. Rev., 27, 1136-1151, 2008.

Sánchez Goñi, M. F., Loutre, M. F., Crucifix, M., Peyron, O., Santos, L., Duprat, J., Malaizé, B., Turon, J.-L., and Peypouquet, J.-P.: Increasing vegetation and climate gradient in western Europe over the Last Glacial Inception $(122-110 \mathrm{ka})$ : models-data comparison, Earth Planet. Sc. Lett., 231, 111-130, 2005.

Schulz, M., Berger, W. H., Sarnthein, M., and Grootes, P. M.: Amplitude variations of 1470-year climate oscillations during the last 100000 years linked to fluctuations of continental ice mass, Geophys. Res. Lett., 26, 3385-3388, 1999.

Shackleton, N. J., Chapman, M., Sanchez-Goñi, M. F., Pailler, D., and Lancelot, Y.: The classic Marine Isotope Substage 5e, Quaternary Res., 58, 14-16, 2002.

Shackleton, N. J., Hall, M. A., and Vincent, E.: Phase relationships between millennial-scale events 64000-24000 years ago, Paleoceanography, 15, 565-569, 2000.

Siddall, M., Rohling, E. J., Almogi-Labin, A., Hemleben, C., Meischner, D., Schmelzer, I., and Smeed, D. A.: Sea-level fluc- tuations during the last glacial cycle, Nature, 423, 853-858, doi:10.1038/nature01690, 2003.

Siddall, M., Stocker, T. F., Blunier, T., Spahni, R., Schwander, J., Barnola, J.-M., and Chappellaz, J.: Marine Isotope Stage (MIS) 8 millennial variability stratigraphically identical to MIS 3, Paleoceanography, 22, PA1208, doi:10.1029/2006PA001345, 2007.

Siegenthaler, U., Stocker, T. F., Monnin, E., Lüthi, D., Schwander, J., Stauffer, B., Raynaud, D., Barnola, J.-M., Fischer, H., Masson-Delmotte, V., and Jouzel, J.: Stable carbon cycle climate relationship during the Late Pleistocene, Science, 310, 1313-1317, doi:10.1126/science.1120130, 2005.

Skinner, L. C. and Shackleton, N. J.: Deconstructing Terminations I and II: revisiting the glacioeustatic paradigm based on deepwater temperature estimates, Quaternary Sci. Rev., 25, 33123321, 2006.

Spahni, R., Chappellaz, J., Stocker, T. F., Loulergue, L., Hausammann, G., Kawamura, K., Flückiger, J., Schwander, J., Raynaud, D., and Jouzel, J.: Atmospheric methane and nitrous oxide of the late Pleistocene from Antarctic ice cores, Science, 310, 13171321, doi:10.1126/science.1120132, 2005.

Stirling, C. H., Esat, T. M., Lambeck, K., McCulloch, M. T., Blake, S. G., Lee, D.-C., and Halliday, A. N.: Orbital forcing of the Marine Isotope Stage 9 Interglacial, Science, 291, 290-293, doi:10.1126/science.291.5502.2902001.

Turon, J.-L.: Le palynoplancton dans l'environnement actuel de l'Atlantique nord-oriental, Evolution climatique et hydrologique depuis le dernier maximum glaciaire, Université de Bordeaux I, 313 pp., Bordeaux, France, 1984.

Tzedakis, P. C.: Towards an understanding of the response of southern European vegetation to orbital and suborbital climate variability, Quaternary Sci. Rev., 24, 1585-1599, 2005.

Tzedakis, P. C., Andrieu, V., de Beaulieu, J.-L., Birks, H. J. B., Crowhurst, S., Follieri, M., Hooghiemstra, H., Magri, D., Reille, M., Sadori, L., Shackleton, N. J., and Wijmstra, T. A.: Establishing a terrestrial chronological framework as a basis for biostratigraphical comparisons, Quaternary Sci. Rev., 20, 1583-1592, 2001.

Tzedakis, P. C., Andrieu, V., de Beaulieu, J.-L., Crowhurst, S., Follieri, M., Hooghiemstra, H., Magri, D., Reille, M., Sadori, L., Shackleton, N. J., and Wijmstra, T. A.: Comparison of terrestrial and marine records of changing climate of the last 500000 years, Earth Planet. Sc. Lett., 150, 171-176, 1997.

Tzedakis, P. C., Frogley, M. R., Lawson, I. T., Preece, R. C., Cacho, I., and de Abreu, L.: Ecological thresholds and patterns of millennial-scale climate variability: The response of vegetation in Greece during the last glacial period, Geology, 32, 109-112, 2004a.

Tzedakis, P. C., McManus, J. F., Hooghiemstra, H., Oppo, D. W., and Wijmstra, T. A.: Comparison of changes in vegetation in northeast Greece with records of climate variability on orbital and suborbital frequencies over the last 450000 years, Earth Planet. Sc. Lett., 212, 197-212, 2003.

Tzedakis, P. C., Roucoux, K. H., de Abreu, L., and Shackleton, N. J.: The duration of forest stages in southern Europe and interglacial climate variability, Science, 306, 2231-2235, doi:10.1126/science.1102398, 2004b.

Viau, A. E., Gajewski, K., Fines, P., Atkinson, D. E., and Sawada, M. C.: Widespread evidence of $1500 \mathrm{yr}$ climate variability in North America during the past 14000 yr, Geology, 30, 455-458, 
2002.

Waelbroeck, C., Labeyrie, L., Michel, E., Duplessy, J. C., McManus, J. F., Lambeck, K., Balbon, E., and Labracherie, M.: Sea-level and deep water temperature changes derived from benthic foraminifera isotopic records, Quaternary Sci. Rev., 21, 295$305,2002$.
Wijmstra, T. A. and Smit, A.: Palynology of the middle part (3078 meters) of the $120 \mathrm{~m}$ deep section in Northern Greece (Macedonia), Acta Bot. Neerl., 25, 297-312, 1976.

Yokokawa, M. and Franz, S. O.: Changes in grain size and magnetic fabric at Blake-Bahama Outer Ridge during the late Pleistocene (marine isotope stages 8-10), Mar. Geol., 189, 123-144, 2002. 